\title{
ERISA PREEMPTION AND FAIR SHARE LEGISLATION
}

\section{"The American health care system is confronting a crisis. The health care delivery system is incapable of meeting the present, let alone the future, needs of the American public...}

\section{... The cost of private health insurance is increasing at an annual rate in excess of 12 percent. Individuals are paying more out of pocket and receiving fewer benefits. One in seven Americans is uninsured, and the number of uninsured is on the rise.”1}

\section{INTRODUCTION}

Every state in America is currently facing the crisis of the uninsured. Not only does this mean that the sick get sicker, but it also means that healthy citizens have no route to preventative care. ${ }^{2}$ At the end of 2004, more than 45 million people, or 17.8 percent of the non-elderly population of our country, were without health insurance. ${ }^{3}$ What is both surprising and disturbing is the fact that the largest population of the uninsured are not indigent, but gainfully employed ${ }^{4}$ low-income adults and their families. ${ }^{5}$ In fact, almost half of the uninsured have family incomes of $\$ 30,000$ or more and one-quarter have total family incomes of $\$ 50,000$ or more. ${ }^{6}$ This problem is not a new one, but a chronic condition that this country first faced during the Reagan Administration when 16.1 percent of the population was uninsured. ${ }^{7}$

1 Robert Pear, US Urged to Test Solutions To a “Crisis” in Health Care, N.Y. TimES, Nov 20, 2002, query.nytimes.com/gst/fullpage.html?sec=health\&res=9505E3DC1639F933A15752C1A9649C8B63 (citing a report from a panel of experts appointed by the National Academy of Sciences).

2 See National Conference of State Legislatures' analysis, http://www.ncsl.org/programs/health/payorplay2006.htm.

$3 \quad$ Carmen DeNavas-Walt, Bernadette D. Proctor, and Cheryl Hill Lee, U.S. Census Bureau, Current Population Reports, P60-229, Income, Poverty, and Health Insurance Coverage in the United States: 2004, U.S. Government Printing Office, Washington, DC, 2005. “In 2004, 45.8 million people were without health insurance coverage...” Id.

$4 \quad$ Patricia A. Butler, Revisiting Pay or Play: How States Could Expand Employer-Based Coverage Within ERISA Constraints, published by the National Academy for State Health Policy, May 2002. "The vast majority of insured Americans receive health coverage through the work place, but over one-third of working people (37 percent) are not covered by their employers.” Id. at 1.

5

Sarah Snider and Sarah Boyce, Sources of Health Insurance and Characteristics of the Uninsured: Analysis of the 1993 Current Population Survey, EBRI Special Report SR-20/Issue Brief no. 145, Employee Benefit Research Institute, January 1994. "Among the 38.5 million non elderly Americans who did not have health insurance coverage in 1992, most were working adults (56.7 percent), while the remainder were children (25.4 percent) and non working adults (17.8 percent)." EBRI Issue Brief No. 145 January 1994 p. 8 "In 1992, 53 percent of the uninsured were in families with incomes under \$20,000 annually.” Id.

$6 \quad$ Edmund F. Haislmaier, State-Based Health Care Solutions: Facts \& Figures, The Heritage Foundation, www.heritage.org/Research/features/issues/issuearea/Healthcare.cfm (citing id.). The Employee Benefit Research Institute study reports that over four-fifths (83.4 percent) of the uninsured live in families with at least one worker; that almost two-thirds (62.1 percent) live in families with at least one full-time, full-year worker; and that almost half (49.7 percent) of all uninsured workers are either employed by businesses with fewer than 25 employees or selfemployed. Id. 
The ultimate result of the growing number of uninsured workers is a large percentage of medically ignored people who will, at some point, become people who require government assistance either through medically needy or full Medicaid programs. ${ }^{8}$ That assistance is

7 Consider the following statistics tracking the insurance coverage of the non-elderly population from 1989 to 2004 .

\begin{tabular}{|l|l|l|l|}
\hline Year & 1989 & 1990 & 1991 \\
\hline $\begin{array}{l}\text { Percentage Receiving } \\
\text { Employment based } \\
\text { Insurance }\end{array}$ & 65.4 & 64.2 & 64.1 \\
\hline Percentage Uninsured & 16.1 & 16.5 & 16.6 \\
\hline
\end{tabular}

(Data excerpted from EBRI Issue Brief No. 145, January 1994, p.5, figure 1)

\begin{tabular}{|l|l|l|}
\hline Year & 1992 & 1993 \\
\hline $\begin{array}{l}\text { Percentage Receiving } \\
\text { Employment based } \\
\text { Insurance }\end{array}$ & 62.0 & 60.8 \\
\hline Percentage Uninsured & 17.8 & 18.1 \\
\hline
\end{tabular}

(Data excerpted from EBRI Issue Brief No. 170, February 1996, p.5, figure 1)

\begin{tabular}{|l|l|l|l|l|l|l|l|l|l|l|l|}
\hline Year & 1994 & 1995 & 1996 & 1997 & 1998 & 1999 & 2000 & 2001 & 2002 & 2003 & 2004 \\
\hline $\begin{array}{l}\text { Percentage Receiving } \\
\text { Employment based } \\
\text { Insurance }\end{array}$ & 64.4 & 64.6 & 64.8 & 65.0 & 65.7 & 66.6 & 66.8 & 65.6 & 64.2 & 63.0 & 62.4 \\
\hline Percentage Uninsured & 15.9 & 16.1 & 16.4 & 16.9 & 17.0 & 16.2 & 16.1 & 16.5 & 17.3 & 17.7 & 17.8 \\
\hline
\end{tabular}

(Data excerpted from EBRI Issue Brief No. 287, November 2005, p.4, figure 1)

$8 \quad$ See Jones Day Commentaries, Can Maryland Make Employers “Pay or Play”?, July 2006, www.jonesday.com/pubs/pubs_detail.aspx?pubID=S3550 (citing Dan Vock, Kathleen Hunter, Pamela Prah, and Erin Madigan, Medicaid-Cost and Complexity Tax Reform Efforts, www.stateline.org, March 7, 2005) (citations omitted).

"Forty years after its introduction, Medicaid has evolved into a budgetary Frankenstein overburdening both the federal treasury and the budgets of all 50 states. At the National Governors Association meeting held in Washington, D.C., in February 2005, Medicaid was identified as the number-one problem facing state governments. When Medicaid was introduced in 1965, this federal-state policy to provide for the medical needs of the poor was so overshadowed by passage of the sweeping Medicare guarantees for every American over the age of 65 that President Johnson barely mentioned it at the signing ceremony.

State and federal governments together are expected to have spent close to $\$ 330$ billion on Medicaid in 2005. Medicaid accounts for 22 percent of total state spending and has become the second-largest item in most state budgets, after elementary and secondary education. In 1985, Medicaid accounted for 8 percent of total state spending. Spending on Medicaid is crowding out funding for many other programs that states provide for education, transportation, and public safety. Because Medicaid is the biggest source of federal revenue for the states, a slight decrease in the federal match can have a big impact on a state's budget. For example, during 2006, the federal government will require states to pay an additional \$527 million for Medicaid. States like New Mexico, Louisiana, and Alaska will be hardest hit and estimate that this reduction in the matching formula will cost them each more than $\$ 70$ million. Rising health-care costs play a large 
primarily provided through state-funded programs ${ }^{9}$ and at the 2005 National Governors Association meeting, the Medicaid crisis was identified as the number one problem facing state governments. ${ }^{10}$ State and federal governments together are estimated to have spent close to \$330 billion on Medicaid in 2005. ${ }^{11}$ In addition, the Medicaid program now accounts for 22 percent of total state spending and has become the second-largest item in most state budgets, after elementary and secondary education spending. ${ }^{12}$ In response, states are desperately trying to increase the number of insured residents - either by requiring employers to provide insurance or by finding new sources of revenue to provide health care. ${ }^{13}$

Maryland is one of the states that have tried to remedy its uninsured crisis. In January 2006, the Maryland Legislature passed a bill mandating that employers contribute to employee health insurance costs. This bill represents part of a nationwide initiative by state legislatures to shift some of the burden of rising health care costs to corporate America. The rationale behind such bills is accountability: Many corporate employers can achieve superior efficiency and profitability by using cheap labor that does not include adequate health care coverage for employees and because of this, many state Medicaid programs end up paying for the health care

part in the increasing cost for Medicaid. Meanwhile, Medicaid enrollment increased by almost one-third between 2000 and 2004, causing higher costs for the states. Medicaid spending jumped by more than 50 percent between 2000 and 2004. Changes in the U.S. workplace have also caused an increase in Medicaid enrollment. Because of spiraling health-care costs, employers are more likely to not offer health-care coverage for their employees, forcing some of the working poor to turn to Medicaid.

Maryland's Fair Share Act (discussed below) is a variation on California's "Pay or Play" legislation that was defeated by referendum in 2003. California's proposed law would have required employers with 50 or more employees to either provide health insurance or pay into a state insurance purchasing pool. At least 15 other state legislatures considered similar "Pay or Play” laws during 2005. Arizona, California, Connecticut, New Hampshire, and Tennessee rejected "Pay or Play" legislation. In Vermont, the governor vetoed a "Pay or Play" bill, while in Maryland, the governor's veto was overridden by the legislature. "Pay or Play" legislation remains active in at least nine states: California, Kentucky, Massachusetts, Minnesota, New York, Oregon, Pennsylvania, Washington, and West Virginia. One reason why so many states are looking into the "Pay or Play" legislation is that health-care costs for the poor (Medicaid) seem uncontrollable. Requiring employers to cover workers with health insurance without tapping into the state budget has become an attractive way to balance the state's budget.” $\underline{I d}$.

Id.

10 Dan Vock, Kathleen Hunter, Pamela Prah, and Eris Madigan, Medicaid - Cost and Complexity Tax Reform Efforts, March 7, 2005, www.stateline.org/live/ViewPage.action?siteNodeId=136\&languageId=1\&contentId=16625.

11 Id. See a complete description of the Medicaid program at: www.cms.hhs.gov/home/medicaid.asp.

12 Id.

$13 \quad$ Id. However, "[d]espite increased flexibility for states to use Medicaid and SCHIP to expand health coverage, it is unlikely that states can cover all their uninsured residents through present public programs or develop new public programs without new revenue sources.” Patricia A. Butler, Revisiting Pay or Play: How States Could Expand Employer-Based Coverage Within ERISA Constraints, published by the National Academy for State Health Policy, May 2002. 
costs of employed individuals. ${ }^{14}$ State legislatures feel these employers should be held accountable for failing to provide proper benefits for their employees and should have to bear part of the cost in ensuring the employees do receive appropriate health care benefits. ${ }^{15}$ Proponents of the Maryland bill and similar legislation in other states argue that employer accountability is needed to ensure the viability of state Medicaid programs and ensure that state residents can continue to receive adequate medical treatment. ${ }^{16}$ Rising health care costs are already a serious problem for state budgets and employers are seen as exacerbating the situation by failing to provide health coverage for their employees. ${ }^{17}$

In an attempt to avoid broad tax hikes as a means of alleviating the states' financial burden in providing health care, many state legislatures have crafted legislation that will generate revenue for Medicaid programs from those employers that currently have the largest amount of uninsured employees. The Maryland Fair Share Act (hereinafter referred to as the "MFSA") was the first of such employee health mandates introduced by a state legislature to become law. The Act required employers with 10,000 or more employees in the state of Maryland to contribute at least $8 \%$ of their payroll to employee health insurance costs. ${ }^{18}$ If an employer failed to meet this spending requirement, it was required to contribute the shortfall to the state in the form of a fee. ${ }^{19}$ These funds were to be used to subsidize Maryland's Medicaid program. ${ }^{20}$

The MFSA and similar forms of "fair share legislation" in other states have encountered stiff opposition from the business community. These bills are viewed as anti-capitalist, and it is often argued that they fail to address the root causes of the health care problem in America namely, the rising cost of healthcare. Furthermore, critics claim that these laws will ultimately reduce wages and drive businesses and jobs away from the states that choose to adopt them. These philosophical and economic arguments are complemented by a broad legal challenge. Specifically, many scholars believe that state-sponsored employer health care mandates are preempted by the Employee Retirement Income Security Act ("ERISA"). ${ }^{21}$ The validity of this belief was immediately tested on the MFSA. The Retail Industry Association - which includes such national employers as Wal-Mart - immediately filed suit in Federal Court seeking to have

\footnotetext{
$14 \quad$ See RILA v. Fielder, 435 F.Supp.2d 481, 496 (D. Md. 2000).

15 See, e.g., Floor debate on Senate Bill 790, 2006 Leg., 421st Sess. (Md. Jan. 12, 2006).

$16 \quad$ See id.

17 See id.

18 “Fair Share Health Care Fund Act” H.B. 1284, 419th Gen. Assem., Reg. Sess. (MD 2005). (adding to the Annotated Code of Maryland, codified as amended at Md.Code Ann., Lab. \& Empl. §§ 8.5-102, 8.5-104(b) (2006)).

19 Id.

20 Id.

$21 \quad$ ERISA is a comprehensive set of laws enacted by Congress to ensure that employees’ pensions and benefits are protected if a company goes under. ERISA addressed "the issue of whether American working men women shall receive private pension plan benefits which they had been led to believe would be theirs upon retirement.” S. Rep. No. 93-127, 93d Cong. 1st Sess. 1 (1973), reproduced in U.S. Senate, Committee on Labor \& Public Welfare, Committee Print, Legislative History of the Employee Retirement Income Security Act of 1974,

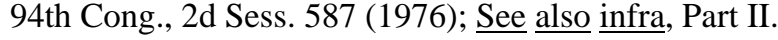


the Maryland law invalidated on the grounds hat it was pre-empted by ERISA. ${ }^{22}$ The District Court of Maryland ruled in favor of RILA and stuck down the Act. ${ }^{23}$ Their ruling was subsequently upheld by the 4th Circuit Court of Appeals, ${ }^{24}$ and the state of Maryland declined to further appeal to the United States Supreme Court.

The Fielder case has pushed the issue of ERISA preemption of state health care laws into the national spotlight. The U.S. Supreme Court has never decided a case challenging an ERISA of a state law that mandates employer health benefit spending. Generally, the Court's pre-emption cases have involved state laws that substantively or procedurally regulate employee health benefits - including the mandating of specific health benefits, ${ }^{25}$ patients' bill of rights, ${ }^{26}$ mixed eligibility decisions, ${ }^{27}$ hospital and medical clinic surcharges targeted at certain health care providers, ${ }^{28}$ and other state health care laws that it deems "relate to" an employer-sponsored ERISA welfare benefit plan. ${ }^{29}$ This is not to say that the MFSA act is an entirely unique piece of state legislation. Over the years there have been countless attempts by states to pass similar legislation, but these attempts have failed. ${ }^{30}$ It is thus no surprise that the Fielder decision spurred wide spread debate over the potential limitations that ERISA imposes on state health care initiatives.

The MFSA raises some important issues that will be addressed below. First, it is necessary to examine the history of the Supreme Court's ERISA pre-emption doctrine, in particular, the Court's landmark ruling in Travelers. ${ }^{31}$ Next, we will analyze the District Court of Maryland and the Fourth Circuit Court of Appeals' decisions in Fielder as well as the more recent case of RILA v. Suffolk County ${ }^{32}$, which was decided on substantially similar grounds. ${ }^{33}$ While this paper ultimately agrees with both courts' findings that acts are preempted under ERISA, it does take issue with how the courts reached their conclusion. This paper will next seek to find a better legal precedent under which employer spending mandates can be analyzed

22 The Supreme Court has agreed and preempted many states' healthcare reform mandates. For a more complete analysis of these cases, see infra, Part II.

$23 \quad$ RILA v. Fielder, 435 F.Supp.2d 481 (D. Md. 2006).

$24 \quad$ RILA V. Fielder, 475 F.3d 180 (4th Cir. 2007)

$25 \quad$ Shaw v. Delta Air Lines, 463 U.S. 85 (1983).

$26 \quad$ Aetna Health Inc. v. Davila, 542 U.S. 200 (2004).

$27 \quad$ Rush Prudential HMO, Inc. v. Moran, 536 U.S. 355 (2002).

$28 \quad$ Blue Cross Blue Shield v. Travelers Ins., 514 U.S. 645 (1995).

29 See, e.g., Mackey v. Lanier Collection Agency \& Service, Inc., 486 U.S. 825 (1988)

30 See, e.g., Vermont and California legislation discussed infra, Part IV.

31514 U.S. 645; See infra, Part I.

32 RILA v. Suffolk County, 06-531 (E.D.N.Y. July 14, 2007) (Westlaw citation not available at date of submission).

33 See infra, Part II. 
and introduces the Ninth Circuit case Standard Oil Co. of California v. Agsalud, ${ }^{34}$ one of the only cases decided by the courts that dealt with a sate-sponsored employer healthcare mandate. ${ }^{35}$ Standard Oil, which found that a "fair share" act in Hawaii was preempted by ERISA, is notably absent from either Fielder opinion. This is somewhat surprising since the case was summarily affirmed by the Supreme Court in 1981. Furthermore, the case is important to ERISA preemption analysis because it seems to be rich in contemporary significance, and may provide courts with a relatively straightforward approach to the question of whether or not employer health care spending mandates are preempted by ERISA. This paper will then look at the impact of our analysis on "fair share" legislation in general to see whether or not such legislation can be structured to better withstand ERISA challenges. ${ }^{36}$ Next, this paper will examine alternative approaches like pay or play taxes and individual mandates to see whether or not these approaches can survive ERISA based preemption challenges. ${ }^{37}$ Finally, the paper will seek to develop a guide for preemption protection of state health care laws. ${ }^{38}$

\section{I: The Historical EVolution Of ERISA AND THE MARYland FAIR SHARE ACT}

The shutdown of the South Bend, Indiana Studebaker plant in December of 1963 is largely regarded as the catalyst behind the drafting and passing of ERISA. ${ }^{39}$ When the plant closed and the company went bankrupt, approximately 4,400 workers their pensions. ${ }^{40}$ Congress enacted ERISA in 1974 to protect employees by implementing standardized retirement plans and providing a regulatory scheme for their administration. ${ }^{41}$ Welfare benefit plans - health or

633 F. 2d 760 (9th Cir. 1980); aff'd, 454 U.S. 801 (1981).

35 See infra, Part III.

36 See infra, Part IV.

37 See infra, Part V.

38 See infra, Part VI.

39 See James A. Wooten, The Most Glorious Story of Failure in the Business: The Studebaker-Packard Corporation and the Origins of ERISA, 49 Buff. L. Rev. 683 (2001).

40 When a Big Company Quits ... the South Bend Story, U.S. News \& World Rep., Dec. 23, 1963, at 76. In December 1963, the Studebaker Corporation announced it was closing its South Bend, Indiana plant. In the process, almost 10,000 workers lost their jobs and almost 4,000 of those who were vested in their pensions lost $85 \%$ of their pension benefits when the plan was terminated. See Private Pension Plans: Hearings Before the Subcomm. on Fiscal Policy of the Joint Economic Comm., 89th Cong. 128 (1966); John H. Langbein \& Bruce A. Wolk, Pension and Employee Benefit Law 54 (2d ed. 1995). For a history of pre-ERISA benefit plans, see G. Waldron Snyder, Employee Retirement Income Security Act of 1974, 11 Wake Forest L. Rev. 219 (1975); Stuart N. Alperin et al., Comment, The Employee Retirement Income Security Act of 1974: Policies and Problems, 26 Syracuse L. Rev. 539 (1975).

41

Jennifer Bender, The Impact of ERISA on California Health Care Law Following the United States Supreme Courts' Pro-Preemption Interpretation, Whittier L. Rev. 26 (Summer 2005). ERISA aimed for national administrative uniformity and protection - creating, for example, the Pension Benefit Guarantee Corporation (PBGC) to protect retirement benefits from employer insolvency. ERISA protects both pension and welfare benefit pans, meaning retirement plans and health or disability plans, respectively. 
disability benefits plans - that are now a common part of health plans were less of a concern in 1974 and therefore were not specifically what Congress sought to protect with ERISA.

In order to maintain that protection and uniformity, the statute polices different types of programs differently. Under the statute, the term "employee benefit plan” encompasses both an employee welfare benefit plan and an employee pension benefit plan." 42 The statute further defines an "employee welfare benefit plan" or "welfare plan" as "any plan, fund, or program which was heretofore or is hereafter established or maintained by an employer or by an employee organization, or by both, to the extent that such plan, fund, or program was established or is maintained for the purpose of providing for its participants or their beneficiaries, through the purchase of insurance or otherwise ..."43

The specific treatment of the two types of plans in ERISA is significantly dissimilar. ERISA extensively and substantively regulates pensions through comprehensive reporting, disclosure, vesting, minimum funding and fiduciary duty requirements, thereby providing protections against mismanagement and under-funding. ${ }^{44}$ Welfare benefit plans do not require long-term policing because they do not involve investment components or possibility of default; employers pay the insurance, employees' health care and unemployment risks are covered,

The purposes and federal jurisdictional hook behind ERISA appear in 29. U.S.C. § 1001:

“(a) ... [T]he continued well-being and security of millions of employees and their dependents are directly affected by these plans ... [ [which] have become an important factor affecting the stability of employment and the successful development of industrial relations . . . and that it is therefore desirable in the interests of employees and their beneficiaries, for the protection of the revenue of the United States, and to provide for the free flow of commerce, that minimum standards be provided assuring the equitable character of such plans and their financial soundness;

(b) ... It is hereby declared to be the policy of this chapter to protect interstate commerce and the interests of participants in employee benefit plans and their beneficiaries, by requiring the disclosure and reporting to participants and beneficiaries of financial and other information with respect thereto, by establishing standards of conduct, responsibility, and obligation for fiduciaries of employee benefit plans, and by providing for appropriate remedies, sanctions, and ready access to the Federal courts;

(c) ... It is hereby further declared to be the policy of this chapter to protect interstate commerce, the Federal taxing power, and the interests of participants in private pension plans and their beneficiaries by improving the equitable character and the soundness of such plans by requiring them to vest the accrued benefits of employees with significant periods of service, to meet minimum standards of funding, and by requiring plan termination insurance.”

29 U.S.C. \& 1001(a)-(c).

29 USC 1002(1). The statute continues on to clarify even further:

"(A): [M]edical, surgical, or hospital care or benefits, or benefits in the event of sickness, accident, disability, death or unemployment, or vacation benefits, apprenticeship or other training programs, or day care centers, scholarship funds; or

(B): [P]repaid legal services; orany benefit described in section 186 (c) of this title (other than pensions on retirement or death, and insurance to provide such pensions).” Id. unduly delayed); ERISA § 302: 29 U.S.C. § 1082 (requiring plans to be adequately funded); ERISA §§ 501-511, 29 U.S.C. $\S \S 1131-1141$ (providing for administration and enforcement). 
incident by incident. Therefore, ERISA exerts much less substantive control over welfare benefit plans. $^{45}$ "[T] ]he gist of all this is that if there is a program for the delivery of an employee benefit other than wages, then presumptively there is an 'ERISA plan' unless an exemption can be found. [Simply] [i]f the plan defers income, it is a pension plan. Otherwise, it is a welfare plan."46 Therefore, by express language within the statute, ERISA regulates the majority of health plans provided by employers and labor unions. ${ }^{47}$

ERISA also preempts state laws "relating to" any employee benefit plan. ${ }^{48}$

To determine whether or not a state law "relates to" an employee benefit plan and is therefore pre-empted by a federal law, the Supreme Court has developed a pre-emption doctrine. This doctrine, which is rooted in the Supremacy Clause of the Constitution, mandates that the preemption of a state law "is compelled [whenever] Congress' command is explicitly stated in the statute's language or implicitly contained in its structure and purpose." 49 Implicit preemption occurs "when compliance with both federal and state regulations is a physical impossibility" or when a state law "stands as an obstacle to the accomplishments and execution of the full purposes and objectives of Congress."

As stated above, ERISA's pre-emption clause pre-empts any state law that relates to an employee benefit plan. While Congress' command here is explicitly stated, the broad scope of the language employed means that for the most part, ERISA preemption cases will turn on Congressional intent. In fact, ERISA's preemption clause really only explicitly describes the type of state laws that are not preempted by ERISA. ${ }^{51}$ Thus, to determine what state laws are pre-empted under ERISA, the courts have been left with the challenging and unenviable task of determining what Congress intended when they included the inherently vague phrase "relates to" in ERISA $\S 514(a)$.

45 See John H. Langbein and Bruse A. Wolk, Pension and Employee Benefit Law, at 176 ( $3^{\text {rd }}$ ed. 2000). See also, Shaw v. Delta Air Lines, 463 U.S. 85, 91 (1983) and case law therein ("ERISA does not mandate that employers provide any particular benefits, and does not itself proscribe discrimination in the provision of employee benefits.”). Appellate courts have even gone so far to state that employers can amend plans at will - even in a discriminatory fashion. See, e.g., Confer v. Custom Engine Co., 952 F.2d 41, 43 (3rd Cir. 1991) (holding that a plan sponsor may change benefits prospectively); McGann v. H\&H Music, Co., 946 F.2d 401 (5th Cir. 1991) (upholding an employer's plan amendment to exclude AIDS treatment).

$46 \quad$ Frank Cummings, article by the American Law Institute 454.

$47 \quad 29$ U.S.C. $\S \S 1001,1003,1109,1132,1144$.

$48 \quad 29$ U.S.C. §1144(a) ("Except as provided in subsection (b) of this section, the provisions of this title and title IV shall supersede any and all State laws insofar as they may now or hereafter relate to any employee benefit plan described in section 4(a) and not exempt under section 4(b).”).

See id. 


\section{A: U.S. Supreme Court ERISA Decisions}

The 1981 case of Aleesi v. Raybestos-Manhattan, Inc. ${ }^{52}$ was the first Supreme Court case to deal with an ERISA based preemption challenge of a state law. In Alessi, retired employees who had received workers' compensation awards subsequent to retirement challenged the validity of provisions in their employers' pension plans that reduced their pension benefits by an amount equal to any workers' compensation awards for which they were eligible. The retired employees challenged the provision under a New Jersey statute, which prohibited pension offsets tied to worker's compensation awards. ${ }^{53}$ The district court found in favor of the employees on the grounds that because ERISA did not itself outlaw such provision, Congress did not intend ERISA to prohibit states from outlawing such offset provisions so the provision was rendered void by amendment to New Jersey Workers' Compensation Act. ${ }^{54}$ The Third Circuit Court of Appeals reversed the decision and found that the New Jersey law was preempted by ERISA and was therefore invalid. ${ }^{55}$ That decision was affirmed by the U.S. Supreme Court. ${ }^{56}$ According to the Supreme Court, the New Jersey law related to and conflicted with pension plans governed by ERISA because it eliminated one method for calculating pension benefits - integration - that was permitted by federal law. ${ }^{57}$

While Alessi was the first ERISA preemption case decided by the Court, it did not offer any guidance as to what type of test the Court would use to determine whether or not a state law "relates to" an ERISA plan. This was a relatively easy case to resolve on preemption issues since the state law clearly conflicted with ERISA. Instead of giving framework for determining whether a case "relates to" an ERISA plan, Alessi established the principle that if a state law is inconsistent or conflicts with ERISA, it will be preempted.

Outside that clear context, the Court's modern day ERISA pre-emption test analyzing the "relate to" aspect pf the preemption clause can be traced back to its decision in Shaw v. Delta Airlines, Inc. ${ }^{58}$ Shaw involved two New York laws - a human rights law that prohibited discrimination in employee benefit plans on the basis of pregnancy and a disability benefits law that required employers to pay sick leave benefits to employees who were unable to work because of pregnancy. The Court found that both laws were pre-empted by ERISA because they "related to" an employee benefit plan. ${ }^{59}$ In reaching their conclusion, the Shaw Court found that “[a] law 'relates to' an employee benefit plan, in the normal sense of the phrase, if it has a 'connection with' or 'reference to' such a plan. Employing this definition, the Human Rights Law ... and the Disability Benefits Law . . . clearly 'relate to' benefit plans. We must give effect

\footnotetext{
52451 U.S. 504 (1981).

$53 \quad$ Id.

$54 \quad$ Aleesi v. Raybestos-Manhattan, Inc., 456 F.Supp. 867, 868 (1978).

$55 \quad$ Buczynski v. General Motors Corp., 616 F.2d 1238 (1980).

Alessi, 451 U.S. 504.

$57 \quad$ Id.

$58 \quad 463$ U.S. 85 (1983).

$59 \quad$ Id. at $85-86$.
} 
to this plain language unless there is good reason to believe Congress intended the language to have some more restrictive meaning." ${ }^{\circ 0}$ The Court felt that this broad and expansive definition of "relates to" was consistent with Congress' desire to eliminate the threat of conflicting or inconsistent State and local regulation of employee benefit plans. ${ }^{61}$ However, the Court did acknowledge, albeit in a footnote, that the breadth of the term "relates to" was not limitless. This important footnote in Shaw states: "Some state actions may affect employee benefit plans in too tenuous, remote, or peripheral a manner to warrant a finding that the law 'relates to' the plan."62

Since Shaw, the challenge has been to determine whether a law is tenuous enough, remote enough, or peripheral enough to escape ERISA's preemption. This language amounted to nothing more than a footnote until the Court chose to revisit the 'relates to' definition some twelve years later in Blue Cross Blue Shield v. Travelers Ins. ${ }^{63}$ In the time between the decisions of $\underline{\text { Shaw }}$ and Travelers, the Court had consistently applied the "relates to" language broadly to find that a state law is preempted under ERISA even where, arguably, the law affected an ERISA plan in a tenuous way. ${ }^{64}$ In the rare instances during that period in which a law did not meet the "relates to" test and was therefore not pre-empted, the Court's conclusions against pre-emption were based on the failure of the state law in question to "relate to" a structure which meets the definition of a "plan" and not on some recognized limitation of the scope of the "relates to" language in the preemption clause. ${ }^{65}$

Travelers is often credited for signaling a paradigm shift towards a relaxation in the Court's construction of ERISA's preemption clause. However, it can be argued that the impetus for the Court's decision can be traced back to Justice Steven's dissent in the case of District of Columbia v. Greater Washington Bd. of Trade. ${ }^{66}$ In that case, the Court pre-empted a District of

$60 \quad$ Id. at 97 (referencing Black's Law Dictionary 1158 (5th ed. 1979) ("Relate. To stand in some relation; to have bearing or concern; to pertain; refer; to bring into association with or connection with”)).

$61 \quad$ Id. at 99. (quoting Senator Williams ("It should be stressed that with the narrow exceptions specified in the bill, the substantive and enforcement provisions of the conference substitute are intended to preempt the field for Federal regulations, thus eliminating the threat of conflicting or inconsistent State and local regulation of employee benefit plans. This principle is intended to apply in its broadest sense to all actions of State or local governments, or any instrumentality thereof, which have the force or effect of law.”) 120 Cong.Rec. 29933 (1974)).

$62 \quad$ Id. at 100.

63514 U.S. 645 (1995).

$64 \quad$ See, e.g., Metropolitan Life Ins. Co. v. Massachusetts, 471 U.S. 724, 739 (1985) (referring to a Massachusetts mental benefits law ("Section 47B clearly "relate[s] to" welfare plans governed by ERISA so as to fall within the reach of ERISA's pre-emption provision, § 514(a).”); Pilot Life Ins. Co. v. Dedeaux, 481 U.S. 41 , 47 (1987) (“There is no dispute that the common law causes of action asserted in Dedeaux's complaint 'relate to' an employee benefit plan and therefore fall under ERISA's express pre-emption clause, § 514(a)); $\underline{\text { See }} \underline{\text { also }}$

Metropolitan Life Ins. Co. v. Taylor, 481 U.S. 58 (1987), Mackey v. Lanier Collection Agency \& Service, Inc., 486 U.S. 825 (1988), FMC Corp. v. Holliday, 498 U.S. 52 (1990); Ingersoll-Rand Co. v. McClendon, 498 U.S. 133 (1990).

65

See, e.g., Fort Halifax Packing Co., Inc. v. Coyne, 482 U.S. 1, 6 (1987) ("[W]e hold that the obligation created by the Maine statute does not involve a plan.”), Massachusetts v. Morash, 490 U.S. 107, 121 (1989) (“It is sufficient for this case that the Secretary's determination that a single employer's administration of a vacation pay policy from its general assets does not possess the characteristics of a welfare benefit plan constitutes a reasonable construction of the statute.”). 
Columbia Workers' Compensation law which required employers who provide health insurance for their employees to provide equivalent health insurance coverage for injured employees eligible for workers' compensation benefits. ${ }^{67}$ The Court found that "Section 2(c)(2) of the District's Equity Amendment Act specifically refers to welfare benefit plans regulated by ERISA and on that basis alone is pre-empted" and reached this conclusion despite the fact that the D.C. law was a worker's compensation law that was explicitly exempted from ERISA preemption under ERISA 4 (b). ${ }^{68}$ The Court reasoned that "[t] he exemptions from ERISA coverage set out in $\S 4$ (b), 29 U.S.C. $\S 1003($ b), do not limit the pre-emptive sweep of $\S 514$ once it is determined that the law in question relates to a covered plan." 69

This reasoning is of concern since it implies that laws that are exempt from ERISA may nevertheless be preempted by ERISA. This would appear to be a broader sweep than what Congress intended. In his dissent in Greater Washington Bd. of Trade, Justice Stevens sharply criticized the majority's ruling. According to Justice Stevens:

"Instead of mechanically repeating earlier dictionary definitions of the word 'relate' as its only guide to decision in an important and difficult area of statutory construction, the Court should pause to consider, first, the wisdom of the basic rule disfavoring federal preemption of state laws, and second, the specific concerns identified in the legislative history as the basis for federal pre-emption. The most expansive statement of that purpose was quoted in our opinion in Shaw. As explained by Congressman Dent, the 'crowning achievement' of the legislation was the 'reservation to Federal authority [of] the sole power to regulate the field of employee benefit plans. With the preemption of the field, we round out the protection afforded participants by eliminating the threat of conflicting and inconsistent State and local regulation.’

The statute at issue in this case does not regulate even one inch of the pre-empted field, and poses no threat whatsoever of conflicting and inconsistent state regulation. By its holding today the Court enters uncharted territory. Where that holding will ultimately lead, I do not venture to predict. I am persuaded, however, that the Court has already taken a step that Congress neither intended nor foresaw."70

Justice Stevens' language suggests that pre-emption would be limited to state laws which are inconsistent or directly in conflict with ERISA.

The Court, apparently influenced by the strong words of Justice Stevens in Greater Washington Bd. of Trade, decided to reexamine the scope of ERISA's preemption clause in Travelers. $^{71}$ Travelers involved a New York statute which required commercial insurers and self

\footnotetext{
$66 \quad 506$ U.S. 125 (1992).

$67 \quad$ Id.

29 U.S.C. $\S 1003(b)(3)$.

$69 \quad$ Greater Washington Bd. of Trade, 506 U.S. at 131.

$70 \quad$ Id. at 138 (Stevens, J., dissenting).

71514 U.S. 645 (1995).
} 
insured funds to pay hospital expenses for covered patients at the standard rate plus a $13 \%$ surcharge. $^{72}$ The Second Circuit Court of Appeals, applying Shaw, found that these "surcharges purposely interfere with the choices that ERISA plans make for health care coverage, and that such interference constitutes a "connection with" an ERISA plan. ${ }^{73}$

The Supreme Court responded to the second Circuit's interpretation of "relates to" by reasoning:

“If 'relate to' were taken to extend to the furthest stretch of its indeterminacy, then for all practical purposes pre-emption would never run its course, for '[r]eally, universally, relations stop nowhere.' But that, of course, would be to read Congress's words of limitation as mere sham, and to read the presumption against pre-emption out of the law whenever Congress speaks to the matter with generality. That said, we have to recognize that our prior attempt to construe the phrase 'relate to' does not give us much help drawing the line here."

The Court continued on to note that:

"[T]his still leaves us to question whether the surcharge laws have a 'connection with' the ERISA plans, and here an uncritical literalism is no more help than in trying to construe 'relate to.' For the same reasons that infinite relations cannot be the measure of preemption, neither can infinite connections. We simply must go beyond the unhelpful text and the frustrating difficulty of defining its key term, and look instead to the objectives of the ERISA statute as a guide to the scope of the state law that Congress understood would survive." 75

The Court's language clearly indicated a desire to square their interpretation of $\S 514$ (a) with Congress' intent. After examining ERISA's legislative history, the Court concluded that the basic thrust of the pre-emption clause "was to avoid a multiplicity of regulation in order to permit the nationally uniform administration of employee benefit plans."76 Thus, for the New York surcharges to be preempted, their purpose and effect had to interfere with the uniform administration of employee benefit plans. ${ }^{77}$ The Court found that they did no such thing. ${ }^{78}$ According to the Court's analysis, the purpose and effect of the New York law was to regulate hospital costs and preserve the viability of the Blues. ${ }^{79}$ Since the regulation of hospital rates is

$\begin{array}{ll}72 & \text { Id. at } 649 \text { (citing N.Y.Pub.Health Law } \S 2807-c(1)(b)) . \\ 73 \quad & \text { Travelers Ins. Co. v. Cuomo, } 14 \text { F.3d 708, } 719 \text { (1993). } \\ 74 \quad \underline{\text { Travelers, }} \text { 514 U.S. at 656, n. } 40 . \\ 75 \quad \underline{\text { Id. at } 656 .} \\ 76 \quad \underline{\text { Id. at } 657 .} \\ 77 \quad \underline{\text { Id. }} \\ 78 \quad \underline{\text { Id. at } 649 .} \\ 79 \quad \underline{\text { Id. at } 657-668 .}\end{array}$


an area that is traditionally reserved to the State, the Court reviewed the law under a presumption against preemption, and found that there was insufficient evidence to overcome this presumption. ${ }^{80}$ The Court did acknowledge that the surcharges had an indirect economic effect on the choices made by insurance buyers, including ERISA plans. ${ }^{81}$ However, the Court reasoned that an "indirect economic influence does not bind plan administrators to any particular choice and thus function as a regulation of an ERISA plan itself."82

It is important to note the use of the word "choice" here because it will become an issue in our discussion of the RILA v. Fielder case. The Travelers Court uses the word to demonstrate that an ERISA plan administrator does not necessarily have to alter the plan terms under the New York law. The administrator merely has to weigh the impact of the higher cost structure that may result from surcharges. This does not bind the administrator to a particular choice of plan structure. There is nothing in this language that suggests the Court was implying that a state law can avoid pre-emption by offering some sort of "choice" for employers or plan administrators.

The implications of Travelers are clear: "[P]reemption does not occur . . . if the state law has only a tenuous, remote, or peripheral connection with covered plans, as is the case with many laws of general applicability." ${ }^{\text {"3 }}$ Nothing in the language of ERISA or the context of its passage indicates that "Congress chose to displace general health care regulation, which historically has been a matter of local concern." ${ }^{44}$ The language of the Court suggest an overwhelming desire to emphasize the presumption against preemption, and to remind the courts that cost uniformity was never a goal of Congress when it passed ERISA.

Travelers is, of course, not without its own limitations. According to Justice Souter, “a state law might produce such acute, albeit indirect, economic effects, by intent or otherwise, as to force an ERISA plan to adopt a certain scheme of substantive coverage or effectively restrict its choice of insurers, and that such a state law might indeed be pre-empted under $\S 514$."85

Notably, the Court in Travelers did not overrule any of its previous opinions, and so they lurk in the background and can be reclaimed by the courts or used as persuasive authority.

While many scholars view Travelers as a major shift in the Court's preemption doctrine, others have argued that it merely clarified the boundaries of preemption. To read more into this clarification would require concluding that the Court intended to abandon some of its earlier preemption decisions. This was not done explicitly and Travelers warrants no such conclusion. Instead, Travelers indicates that the appropriate inquiry under Shaw to determine whether or not a state law has a "connection with" an employee benefit plan requires courts to look "to the objectives of the ERISA statute" as well as "to the nature of the effect of the state law on ERISA plans." 86 In applying the Travelers test, the Court in $\underline{\text { Dillingham }}^{87}$ and De Buono v. NYSA-ILA
$80 \quad$ Id.
$81 \quad$ Id. at 659.
82 Id.
$83 \quad$ Id. at 661.
84 Id.
$85 \quad$ Id. at 668.
$86 \quad$ California Div. of Labor Standards Enforcement v. Dillingham Const., N.A., Inc., 519 U.S. 316, 325
(1997). 
Medical and Clinical Services Fund ${ }^{88}$ declined to pre-empt state laws that had similar indirect effects on ERISA plans. In Dillingham, the Court found that a California prevailing wage statute that regulated state apprenticeship programs was not preempted by ERISA. ${ }^{89}$ The Court reasoned that the wage statute altered the incentives, but did not dictate the choices facing ERISA plans. ${ }^{90}$ In this regard, it was "no different from[the] myriad state laws in areas traditionally subject to local regulation, which Congress could not possibly have intended to eliminate. ${ }^{91}$ In De Buono, the Court upheld a New York state tax on gross receipts for patient services at health care facilities, despite the fact that NYSA-ILA Medical and Clinical Services Fund administered an ERISA plan, and was thus by virtue of directly owning some health services facilities, subject to a direct tax. ${ }^{92}$ The Court reasoned that the tax was an indirect economic effect on their ERISA plans much like the surcharges in Travelers. ${ }^{93}$

The Court's rulings in these cases involve a class of state laws that had a limited and indirect impact on ERISA plans. They did not involve issues of administration, remedies, or attempts to mandate specific benefits. They were exactly what the Court found them to be, i.e., laws that regulate areas of traditional state concern. The state laws at issue in these cases exhibit two identifiable characteristics. First, they target an area of traditional state regulation, and, in doing so have a purpose that seemingly is in no way focused on an ERISA plan. Second, the effect they have on an ERISA plan amounts to nothing more than an indirect cost that doesn't bind plan administrators to any particular choices.

A potential retrenchment from the Travelers line of cases may be supported by the Court's recent holding in Egelhoff v. Egelhoff. ${ }^{94}$ However, a close reading of Egelhoff reveals consistency with the Alessi case, indicating that preemption in Egelhoff was most likely the result of a direct conflict with ERISA. Egelhoff centered on Washington state statute that revoked any interest in a non-probate asset that a former spouse may have had prior to the dissolution or invalidation of a marriage. In the case, Mr. Egelhoff, a married man, had designated his wife as the beneficiary of his life insurance and pension plan - both plans which were governed by ERISA. Mr. Egelhoff then divorced his wife and two months after that, he died. Under the terms of his plan, the proceeds of his life insurance policy were paid to his exwife. Relying on the Washington statute, Mr. Egelhoff's children by a different marriage sued Mrs. Egelhoff in state court to recover the insurance proceeds. The Washington Supreme Court held that ERISA did not preempt the state statute and therefore, the beneficiary designation was revoked by operation of law. ${ }^{95}$ The court reasoned that "although applicable to 'employee

\begin{tabular}{ll}
\hline 87 & $\underline{\text { Id. }}$ \\
88 & 520 U.S. 806 (1997). \\
89 & Dillingham, 519 U.S. at 319. \\
90 & $\underline{\text { Id. at } 334 .}$ \\
91 & $\underline{\text { Id. }}$ \\
92 & $\underline{\text { De Buono, } 520 \text { U.S. } 806}$ \\
93 & $\underline{\text { Id. }}$ \\
94 & 532 U.S. 141 (2001).
\end{tabular}


benefit plan[s],' [the statute] does not 'refer to' ERISA plans to an extent that would require preemption, because it does not apply immediately and exclusively to an ERISA plan, nor is the existence of such a plan essential to operation of the statute." ${ }^{\prime 6}$ The U.S. Supreme Court, however, overturned this ruling, finding that the statute in question was pre-empted by ERISA. ${ }^{97}$ In reaching its decision, the Court relied on three themes: the uniformity theme, the conflict preemption theme, and the "connection with" theme. All three of these themes can be found in the Court's language.

"We recognize that all state laws create some potential for a lack of uniformity. But differing state regulations affecting an ERISA plan's system for processing claims and paying benefits impose precisely the burden that ERISA pre-emption was intended to avoid. And as we have noted, the statute at issue here directly conflicts with ERISA's requirements that plans be administered, and benefits be paid, in accordance with plan documents. We conclude that the Washington statute has a "connection with" ERISA plans and is therefore pre-empted."98

The Court further noted that the Washington statute interferes with the national uniform administration of ERISA plans, under the conflict pre-emption theme.

"Plan administrators cannot make payments simply by identifying the beneficiary specified by the plan documents. Instead they must familiarize themselves with state statutes so that they can determine whether the named beneficiary's status has been 'revoked' by operation of law. And in this context the burden is exacerbated by the choice-of-law problems that may confront an administrator when the employer is located in one State, the plan participant lives in another, and the participant's former spouse lives in a third. In such a situation, administrators might find that plan payments are subject to conflicting legal obligations."99

The Court's reasoning shows how the Washington statute clearly conflicts with ERISA and therefore it is not difficult to reconcile the Court's holding in Egelhoff with the Travelers line of cases on the conflict pre-emption theory. However, the Court in Egelhoff could have resisted the temptation to preempt using other aspects of Travelers because the Washington statute dealt exclusively with matters of family and probate law. These are clearly areas of traditional state regulation which the Court in Travelers would not pre-empt. Furthermore, the statute's impact on an ERISA plan is arguably incidental and its effect on uniform plan administration is extremely limited. The state statute reconciles important family and probate law issues. Specifically, it recognizes that most individuals, after a divorce, will not want to keep their former spouses as beneficiaries on non-probate assets. The state law then proceeds to

$\begin{array}{ll}95 & \text { 139 Wash.2d } 557 \text { (1999). } \\ 96 & \underline{\text { Id. }} \\ 97 & \underline{\text { Egelhoff, }} \text { 532 U.S. 141. } \\ 98 & \underline{\text { Id. at } 150 \text { (citations omitted). }} \\ 99 & \underline{\text { Id. } \text { at } 148-149 .}\end{array}$


offer a remedy that might address any inequities that might arise when a person dies suddenly without having had the opportunity to change the beneficiary designations in any of his nonprobate assets. Under Travelers and its progeny, the Court could have upheld the Washington statute.

Therefore, upon a thorough analysis, it is evident that the Washington law merely addresses issues of family law and probate law - as it specifically provides guidance as to what constitutes a valid beneficiary in Washington. The Washington legislature made a policy decision to favor offspring over former spouses with respect to the distribution of non-probate assets. This does not prevent the administration of a uniform ERISA plan because administrators can continue to pay out designated plan beneficiaries. The law only will come into play when an intestate decedent still has an ex-wife as a listed beneficiary. It is not the type of law that may require administrators to familiarize themselves with the laws of all 50 states. One might assume that when a plan administrator pays out to a designated spousal beneficiary that any conflicts as to the validity of a marriage would be resolved under state law. The same can be said for the construction of signatures on plan documents. These are clearly areas of state law that plan administrators will have to rely on to resolve potential conflicts. Congress could not have intended to extend pre-emption to all these fields. For these reasons, the Court's decision in Egelhoff can really be seen as in line with Alessi - state statutes will be pre-empted when they clearly conflict with ERISA - and not a potential retrenchment from Travelers and similar cases.

While Travelers and its progeny suggest a potential blueprint that legislatures may follow to avoid preemption, the Court's unwillingness to expressly overrule $\underline{\text { Shaw }}^{100}$, Greater Washington $\underline{B d}$. of Trade $^{101}$, or other broad preemption cases spins ERISA's preemption doctrine into a tangled web because at times it is seemingly plain and visible, but in certain instances, one may find oneself entangled with no way out that preserves jurisprudential integrity. This is largely due to the fact that the Courts have been trying to rectify through interpretation what congress has befuddled through legislation. It is against this backdrop that we find the Maryland Fair Share Act.

\section{B: The Maryland Fair Share Act}

The MFSA ${ }^{102}$ was signed into law on January 12, 2006. It covers all non-governmental employers with 10,000 or more employees in the State of Maryland. The Act requires a forprofit employer to spend an amount equal to at least $8 \%$ of total wages paid to the employer's Maryland employees on "health insurance costs."103 A non-profit employer is required to spend an amount equal to $6 \%$ of the total wages paid to employees in the State of Maryland on "health insurance costs."104 An employer that fails to meet the required spending threshold must pay an amount equal to the difference between what the employer spends on "health insurance costs"

\footnotetext{
$100 \quad$ Shaw v. Delta Air Lines, 463 U.S. 85 (1983).

$101 \quad$ District of Columbia v. Greater Washington Bd. of Trade, 506 U.S. 125 (1992).

102 Fair Share Health Care Fund Act, 2006 Md. Laws ch. 3 (codified as amended at Md. Code Ann., HealthGen. § 15-142 (West 2006); Md. Code Ann., Lab. \& Empl. §§8.5-101 to 107(West 2006)).
}

103 Fair Share Health Care Fund Act $\S 1$. 
and the required amount to the Secretary of Maryland. ${ }^{105}$ The Secretary will then place the funds in the Maryland Fair Share Health Care Fund, which will be used to help finance Maryland's Medicaid program. If an employer fails to make the payment, they may be subject to a $\$ 250,000$ fine. ${ }^{106}$ Under the law, "health insurance costs” are defined as any payments made for medical care, prescription drugs, vision care, medical savings accounts, and any other costs to provide health benefits as defined in \$213(d) of the Internal Revenue Code. ${ }^{107}$ The Act also includes reporting requirements that call for employers to submit an annual report to the Maryland Department of Labor, Licensing, and Regulation stipulating the number of its employees and the amount and percentage of payroll that was spent on health insurance costs during the preceding calendar year. An employer will face a \$250 penalty for each day that the report is delinquent. ${ }^{108}$ In the State of Maryland, Wal-Mart is the only covered employer that fails to meet the state's spending requirements and would therefore be required to pay the fee. For this reason, the Maryland Fair Share Act is commonly referred to as the "Wal-Mart Law."

\section{II: RILA V. FIELDER AND RILA v. SUFFOLK COUNTY}

The MFSA was immediately challenged by the Retail Industry Leaders Association (RILA). ${ }^{109}$ RILA filed suit in the U.S. District Court for the District of Maryland seeking declaratory and permanent injunctive relief against James D. Fielder, Jr. in his official capacity as Maryland Secretary of Labor, Licensing and Regulation. RILA alleged that the MFSA was an unlawful intrusion on the comprehensive federal framework for the administration and regulation of employee benefit plans and, accordingly, is preempted by the Employee Retirement Income Security Act of $1974 .{ }^{110}$ The district court held that the Act was preempted by ERISA and granted summary judgment in favor of the plaintiff. ${ }^{111}$

RILA v. Fielder is the first ERISA-based preemption challenge of a "fair share" law to be decided by a court. In light of the avalanche of similar legislation currently being considered by the states, RILA has potentially far reaching implications for state-based health care initiatives. The district court's decision was based on its interpretation of the Supreme Court's ERISA preemption doctrine. The court found that the MFSA imposed an employee health or welfare mandate on employers and was thus invalid under ERISA. ${ }^{112}$ In reaching his conclusion, Judge Motz applied the Shaw Court's test that a law "relates to" an ERISA plan if it has either a "connection with" or makes a "reference to" such a plan. ${ }^{113}$ The court ultimately concluded that

\footnotetext{
105 Id.

$106 \quad$ Id.

107 Id.

108 Id.

$109 \quad$ RILA v. Fielder, 435 F.Supp. 2d 481 (D. Md. 2005)

$110 \quad$ Id. at 484.

$111 \quad$ Id. at 484.

$112 \quad$ Id. at 496.

$113 \quad$ Id. at 495.
} 
the MFSA had a connection with an ERISA plan, and was thus preempted under Section 514(a). ${ }^{114}$ We believe that the court's findings were correct, and that the MFSA is preempted under both Shaw and Travelers.

In reaching his conclusion, Judge Motz applied the Travelers Court's interpretation of the "relates to" test. As we previously discussed, the Travelers Court found that a court's "connection with" inquiry must look to: (1) the objectives of the ERISA statute as a guide to the scope of the state law that Congress understood would survive; and (2) the nature of the effect of the state law on ERISA plans. ${ }^{115}$ With respect to the first factor, the district court in Fielder correctly concluded that the MFSA should be preempted because it created "health care spending requirements that were not applicable in most other jurisdictions."116 According to Travelers, the main objective of ERISA's preemption clause is "to avoid a multiplicity of regulation in order to permit the nationally uniform administration of employee benefit plans."117 At the time the MFSA was passed, there were 27 other states proposing "fair share” bills. The spending requirements in those bills ranged from $6 \%$ to $11 \%$. The court reasoned that if "fair share" laws like the MFSA are not preempted by ERISA, a national employer will be forced to tailor their ERISA plans to a wide variety of legislation. ${ }^{118}$ This would inherently defeat Congress' uniformity goal because employers like Wal-Mart could face spending requirements in fifty different states and a limitless amount of local jurisdictions - contrary to the explicit Congressional intent behind ERISA. ${ }^{119}$

The district court also correctly concluded that the MFSA fails the second part of the "connection with" inquiry. ${ }^{120}$ The purpose of the MFSA is to force employers that do not provide sufficient healthcare coverage for their employees to increase coverage to a state mandated level. ${ }^{121}$ Since employee health benefits are generally provided by an ERISA plan, the MFSA is aimed directly at such a plan. Furthermore, the effect of the act will be that employers will have to alter the structure and administration of their ERISA plans. Once the court correctly concluded that the Act satisfied the "connection with” inquiry delineated in Travelers, it was forced to preempt it under Shaw.

In reaching this conclusion, Judge Motz was not persuaded by the Secretary of Maryland's argument that the Act should not be preempted under Travelers and its progeny because it share similar characteristics with laws the Travelers Court said should not be preempted. ${ }^{122}$ Had the Secretary relied more heavily on a purposeful analysis of the preemption

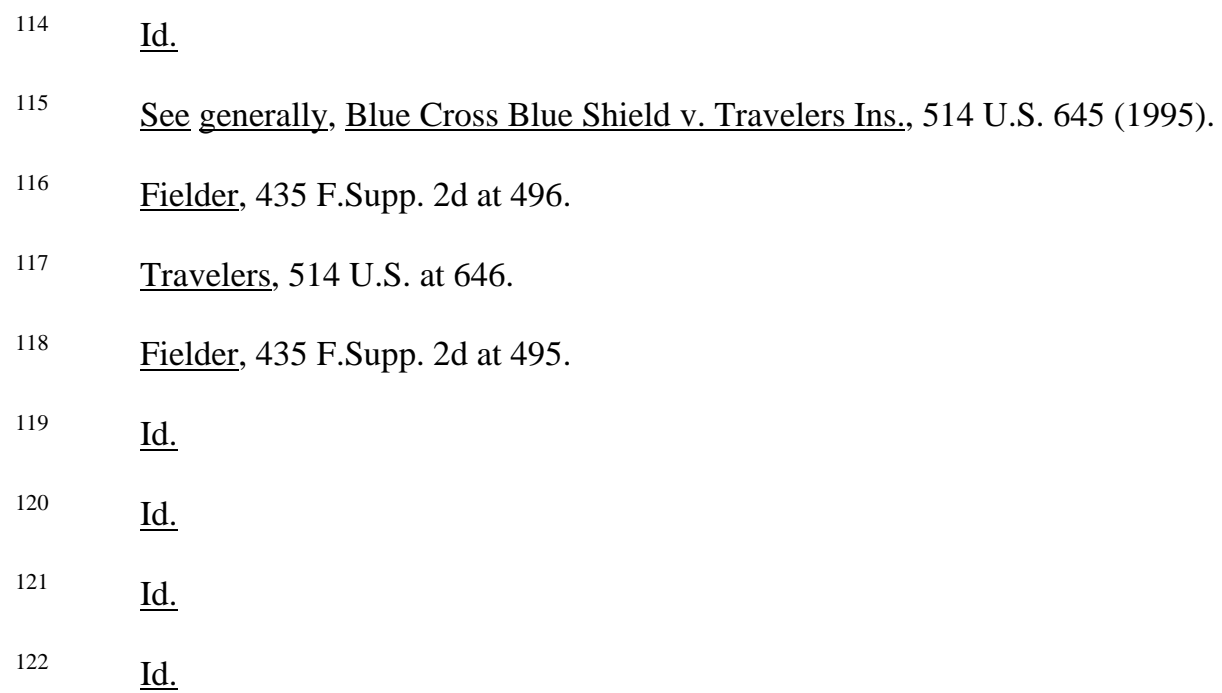


clause, the legislative history of broad preemption, and the argument that the MFSA deals with a traditional area of state regulation, he may have made a more persuasive argument against preemption. According to the Secretary, the Maryland Act was comparable to the state laws that were not preempted in the Travelers trilogy. ${ }^{123}$ In relying on Travelers, the Secretary argued that a state law that has an indirect economic impact on an ERISA plan should not be preempted as a benefits mandate if it provides employers with a choice - in other words, it is not a mandate if there is a choice. ${ }^{124}$ According to this argument, a covered employer can comply with the Act by spending money on non-ERISA plan health coverage or by paying a fee to the state, which is a clear choice. ${ }^{125}$ The Secretary of Maryland's argument further reasons that since both these means of compliance do not interfere with plan administration or structure, the Act should not be preempted. $^{126}$

The problem with this argument is that it is based on a misreading of Travelers. Some analysts seem to believe that the Travelers Court created a new test when it used the word "choice" in its analysis of the New York surcharges, but this was not the case. In actuality, the word "choice" was used to demonstrate the "indirect economic effect" the surcharges had on ERISA plans. Because many factors go into plan pricing, an ERISA plan such as the one in Travelers would be able to choose whether or not it wants to switch to the alternative coverage to avoid the surcharges or remain with their current provider and pay the surcharges. While the surcharges created an incentive to switch, they did not necessarily force a switch. The same can be said of the state laws in Dillingham and De Bueno. The word "choice" is used within the context of the Court's argument to demonstrate the tenuous connection between the state law and an ERISA plan. It has a descriptive purpose. The Court wanted to illustrate that Congress had no intention of preempting state hospital regulations when it enacted ERISA. With the regulation intact for preemption purposes by virtue of both its "purpose and effect," the Court was required to uphold the law. Within the context of this valid law, the rest of Travelers was about the Court acknowledging that the law produced an indirect economic effect on ERISA plans. Almost any acceptable state health care regulation will somehow indirectly impact an ERISA plan. The Travelers Court did, however, say that one day an otherwise acceptable state law might produce such "acute, albeit indirect, economic effects, by intent or otherwise, as to force an ERISA plan to adopt a certain scheme of substantive coverage or effectively restrict its choice of insurers, and that such a state law might indeed be pre-empted under $\S 514$."127 The Secretary of Maryland argued that Travelers created an exception to preemption in that a state law can avoid preemption if it offers employers' choices to comply that do not relate to an ERISA plan. However, the Court's current ERISA preemption doctrine doesn't support this argument.

According to the Secretary of Maryland, an employer could meet the state's spending threshold requirement through non-ERISA health care spending - namely on-site medical clinics

$\begin{array}{ll}123 & \text { Id. at 495-96. } \\ 124 & \underline{\text { Id. }} \\ 125 & \underline{\text { Id. }} \\ 126 & \underline{\text { Id. }} \\ 127 & \text { Blue Cross Blue Shield v. Travelers Ins., } 514 \text { U.S. 645, } 668 \text { (1995). }\end{array}$


and Health Savings Accounts. ${ }^{128}$ The district court, however, rejected the medical clinic option on the grounds that "they simply would not be a serious means by which employers could increase health care spending to comply with the fair share act." ${ }^{\text {"29 }}$ This was based on the fact that in order for the clinics to qualify as non-ERISA clinics they must be maintained for the "treatment of minor injuries or illness or rendering first aid in the case of accidents occurring during working hours." ${ }^{, 30}$ We would have to agree with the judge's conclusion. Consider the hypothetical employer that does not currently offer an employee benefit plan or anything that would fall within the category of health insurance costs. This employer could theoretically comply with the MFSA by spending $8 \%$ of their payroll on medical clinics to treat minor injuries. This certainly was not what the Maryland legislature intended when it passed the act. The goal of the legislation was to force employers with employees that were deemed to be burdening the Medicaid system to expand their coverage. Employee health care needs are largely covered through an ERISA plan that provides ongoing coverage for them, and not by first aid clinics. Thus, if the purpose and effect of the MFSA was to increase health care coverage through employee benefit plans, the Secretary of Maryland cannot seriously argue for a compliance method that directly contradicts the intended purpose of the law just because it provides a means to avoid ERISA pre-emption.

The Secretary also argued that the MFSA act should not be pre-empted because employers could satisfy the spending requirement by contributing to Health Savings Accounts ("HSA's") for employees. ${ }^{131}$ According to a DOL advisory opinion, "HSA's are personal health care savings vehicles rather than a form of group health insurance" and therefore they are not subject to ERISA. ${ }^{132}$ Because of this DOL exemption, the Secretary argued that HSA contributions allowed for compliance with the MFSA in a manner that did not affect the uniform administration of employee benefit plans. ${ }^{133}$ The court correctly rejected this argument. The fact that this argument was raised, however, is further evidence of the complications that arise when one tries to analyze legislation mandating employer spending on health care benefits within the context of the current ERISA pre-emption case law. The DOL has stated that just because an employer sponsors a qualifying High Deductible Health Plan that makes the creation of an HSA possible, and may even contribute funds to the HSA directly - that in and of itself does not bring ERISA into play. ${ }^{134}$ Thus, the MFSA is crafted under the assumption that this is a means of nonERISA spending that an employer can use to meet the $8 \%$ requirement. However, for an HSA to be considered a non-ERISA plan, an employee's participation must be entirely voluntary. ${ }^{135}$ The question then becomes how employers can meet a regulatory spending requirement when their

\begin{tabular}{ll}
\hline 128 & Fielder, 435 F.Supp. 2d at 497. \\
129 & Id. at 497-498. \\
$130 \quad \underline{\text { Id. }}$ \\
$131 \quad$ Id. at 497. \\
$132 \quad \underline{\text { Id. }}$ \\
$133 \quad \underline{\text { Id. }}$ \\
$134 \quad$ Id.
\end{tabular}

Gary B. Kushner, More Good News on Health Savings Accounts: DOL Rules HSAs Not ERISA Plans. 
employees don't even need to establish HSA's. The simple answer to this question is they can't. Employers could theoretically issue an internal memo to all employees explaining that they would like to provide them with some level of coverage through contributions to HSA's, but that they cannot do so until such HSA's are voluntarily established by them. They could even go on to say that if the employees choose to not create HSA's, that they will be forced to donate this money to the state, and that the employees will then have to use Medicaid to extract these benefits from the state. Of course, employers would have to do this while maintaining neutral language about what choice they would prefer their employees to make. This example demonstrates the obvious problem with the Secretary's HSA argument. Simply put, the Secretary failed to realize that if you strip the HSA's of their voluntary nature, all that will be left is an ERISA regulated benefit plan.

The Secretary next argued that even if employers had to alter the structure of their ERISA plans so as to offer more high deductible health care plans to make HSA contributions feasible, these required changes did not constitute a "relation to" or "connection with" an ERISA plan. ${ }^{136}$ According to the Secretary, these changes would amount to nothing more than an indirect cost to ERISA plans and indirect costs are entirely permissible under Travelers. ${ }^{137}$ One can argue that the MFSA is seemingly structured with the intention of creating "indirect" effects for the sole purpose of avoiding pre-emption. If the court accepts this argument that directly creating indirect effects is an acceptable way to avoid preemption of "fair share" laws, it opens the door to new and novel mandated employer health care legislation that provides choices and indirect effects particularly tailored to avoid preemption.

The Secretary continued his "choice” argument by calling the court's attention to the alternative compliance option offered by the MFSA. ${ }^{138}$ The Secretary argued that the Act doesn't require an employer to increase health care spending. ${ }^{139}$ It merely requires that a covered employer pay the state an amount equal to the difference between their actual health care costs and the required amount. ${ }^{140}$ Thus, the Act doesn't bind plan administrators to a particular set of choices, and is thus not related to an employee benefit plan. ${ }^{141}$ The court rejected this argument on the grounds that the choice offered by the MFSA was a Hobson's choice. ${ }^{142}$ The court reasoned that an employer faced with the choice of whether to pay the state or pay for the care of its employees would always choose to pay for its employees. ${ }^{143}$ Judge Motz further supported this argument by citing a Wal-Mart affidavit stating that the company would increase spending if the law were upheld. ${ }^{144}$ While we believe the court correctly rejected the Secretary's argument

\begin{tabular}{ll}
\hline 136 & $\underline{\text { Fielder, 435 F.Supp. 2d at 497. }}$ \\
137 & $\underline{\text { Id. }}$ \\
138 & $\underline{\text { Id. }}$ \\
139 & $\underline{\text { Id. }}$ \\
140 & $\underline{\text { Id. }}$ \\
141 & $\underline{\text { Id. }}$ \\
142 & $\underline{\text { Id. }}$ \\
143 & $\quad \underline{\text { Id. }}$
\end{tabular}


against preemption simply because employer's have the option of paying the state a fee, we do not agree with his conclusion that this was the Hobson's choice the Supreme Court was referring to in Travelers. Once again shows a misreading of Travelers. The MFSA incorporates a compliance choice for covered employers. The choice is part of the law. The courts must still determine if the law regulates ERISA plans. The Hobson's choice discussed in Travelers requires an otherwise acceptable state law. Thus, before you can raise the Hobson's choice argument, you would need to conclude that an 8\% "health insurance cost" spending requirement does not directly relate to an ERISA plan and is valid under ERISA preemption. Any choices that exist within a law are not choices but means of compliance. The following is an example of what would constitute a Hobson's choice under Travelers. If the New York hospital surcharges in Travelers had been set at 100\%, the Supreme Court may have determined they amounted to a Hobson's choice for an ERISA plan and invalidated them because a 100\% surcharge would mean that every employer that did not currently purchase coverage from the Blues would switch to the Blues to avoid the surcharges. There would be no economic choice for employers or plan administrators to make. The important distinction between these two scenarios is that the surcharge law would still survive a preemption challenge if it was analyzed on its face. This is because the law would be regulating hospitals and not plans. However, as we have shown, in this hypothetical situation the entirely permissible state regulation of hospitals would produce an indirect cost on ERISA plans that would force employers to adopt a certain form of coverage. Such a law would be preempted under the reasoning of Travelers even if it regulated an area of traditional state concern.

The Secretary of Maryland appealed the district court's ruling to the U.S. Court of Appeals for the Fourth Circuit. ${ }^{145}$ The Fourth Circuit affirmed the district court's ruling. ${ }^{146}$ There are only a few subtle differences between the Fourth Circuit opinion and the district court opinion. Both opinions rely on the Supreme Court's preemption doctrine, specifically, Shaw and Travelers, to reach their conclusion. The Fourth Circuit does, however, manage to avoid exposing itself to the district court's reasoning of the "choice" argument. This is accomplished by clearly distinguishing the facts in Travelers and Dillingham from the facts at hand. The court correctly found that:

"In contrast, to Travelers and Dillingham, the Fair Share Act directly regulates employers' structuring of their employee health benefit plans. This tighter casual link between the regulation and employers' ERISA plans makes the Fair Share Act much more analogous to the regulations at issue in Shaw and Egelhoff, both of which were found preempted by ERISA."147

The court also found that with respect to the payment fee option of the MFSA:

"The existence of this stylized scenario, however, does nothing to refute the fact that in most scenarios, the Act would cause an employer to alter the administration of its

\footnotetext{
$144 \quad$ Id.

$145 \quad$ RILA v. Fielder, 475 F.3d 180 (4th Cir. 2007).

$146 \quad$ Id. at 184.

147 Id. at 195-96.
} 
healthcare plans. Indeed, identifying the narrow conditions under which the Act would not force an employer to increase its spending on healthcare plans only reinforces the conclusion that the overwhelming effect of the Act is to mandate spending increases.”148

Judge Michael filed a dissenting opinion, in which he entirely accepted the Secretary of Maryland's argument. He wrote:

"I respectfully dissent on the issue of ERISA preemption because the Act does not force a covered employer to make a choice that impacts an employee benefit plan. An employer can comply with the Act either by paying assessments into the special fund or by increasing spending on employee health insurance. The Act expresses no preference for one method of Medicaid support or the other. As a result, the Act is not preempted by ERISA."149

Judge Michael focused his analysis on the payment fee option that the MFSA offers employers. He reasoned that the choice to pay a fee to the state or increase benefits is a business judgment that Wal-Mart is free to make. ${ }^{150}$ However, we do not think the MFSA does implicate standard business judgment. The MFSA is a state law that Wal-Mart must comply with. Wal-Mart has no choice. Now, as a means of making compliance easier, the state is willing to accept a direct payment. This does not amount to a business judgment because it is a compliance decision and not a cost decision. It may have elements of a cost decision, but for most part it is all about complying with the law.

Finally, Judge Michael concluded that “[t]he statutes in Travelers and Dillingham were permissible regulations of ERISA plans primarily because they did not mandate a particular level of benefits or impact plan administration, not because of the non-ERISA targets of the regulations."151 However, the whole point of the Travelers trilogy is to keep ERISA out of state laws that are in no way designed to regulate ERISA plans or the benefits provided by ERISA plans. The Court needed language that would limit the reach of their "relates to" test whenever a law that did not target an ERISA plan was challenged under ERISA's preemption clause. Travelers provided this language specifically to protect states rights in non-ERISA targeted fields of regulation.

\section{RILA v. Suffolk County}

Following the decision of Fielder, ${ }^{152}$ a lawsuit was brought in United States District Court for the Eastern District of New York seeking a declaratory judgment that a Suffolk County law substantially similar to the MFSA was invalid because it was pre-empted by ERISA. ${ }^{153}$ The
$148 \quad$ Id. at 197.
$149 \quad$ Id. at 201.
$150 \quad$ Id.
$151 \quad$ Id. at 203.
152 Id.
153 RILA v. Suffolk County, No. 06-531 (E.D.N.Y. July 14, 2007) (Westlaw citation not available at date of submission). 
Retail Industry Leaders Association sued Suffolk County as well as County Executive Steve Levy and County Commissioner of Labor Robert W. Dow, Jr.

The Suffolk County Fair Share for Health Care Act required that covered employers make minimum "employee health care expenditures" equivalent to the "public health care cost rate multiplied by the total number of hours worked" by their employees in Suffolk County. ${ }^{154}$ The Act was designed to ensure that the public health care cost rate was equivalent to the cost that the state's health system bears to provide health care to uninsured employees. ${ }^{155}$ The Act defined health care expenditures as "any amount paid by a covered employer to employees or to another party for the purpose of providing health care services or reimbursing the cost of such services for employees or family of employees." Act gave employers four alternative categories of health care expenditures that would satisfy their payment obligations:

“(i) contributions by a covered employer to a health savings account, as defined under Section 223 of the United States Internal Revenue Code or to any other account having substantially the same purpose of effect without regard to whether such contributions qualify for tax deduction or are excludable from employee income;

(ii) reimbursement by a covered employer of health care expenses incurred by its employees or the family of its employees, whether or not the employees had any preexisting entitlement to such reimbursement under any plan, fund, or program maintained by the employer;

(iii) expenditures made by a covered employer to operate a work place health clinic or to provide any health-related services to employees in the workplace; and

(iv) contributions by a covered employer to any federally qualified health center or other community center.”"157

In addition, any covered employer whose health care expenditures fell short of the requirements would have to pay a penalty equal to the shortfall. ${ }^{158}$ The Act also gave Suffolk County the authority to order penalties and fines for employers who did not comply. ${ }^{159}$ Similar to the MFSA, the Act was designed to protect the county from incurring the costs of health care brought by large employers who do not provide adequate health care for their employees. The Suffolk County Act was also implemented to protect small employers who felt a need to compete with large employers and thus had to eliminate employee health insurance to gain a competitive advantage. $^{160}$

154

155

Id.; See also Suffolk County Reg. Local Law § 325-1, 2, 3, 4.

Id.

Id. Suffolk County Reg. Local Law. § 325-2.

Id.

Id.

RILA v. Suffolk County, No. 06-531 (E.D.N.Y. July 14, 2007). 
The district court used the Fielder case from the 4th Circuit as guidance and applied the same substantive principles as the court had outlined. The Suffolk Court began by outlining the principles of ERISA - to ensure that there is comprehensive and uniform regulation of employee benefit plans with a standard set of procedures and guidelines to aid employers in processing claims and awarding benefits. ${ }^{161}$ The court next addressed the Supreme Court precedents of

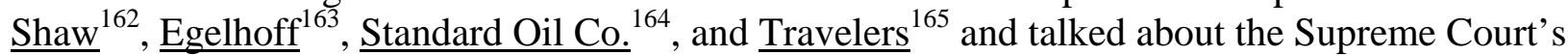
doctrine relating to ERISA. ${ }^{166}$

The court continued on and discussed both the district court and appellate court decisions in Fielder, ultimately deciding that the Suffolk County case was substantially similar to that one and reaching the same conclusion on the issue of pre-emption.

Suffolk County made a series of arguments which the Court found unpersuasive, which are very much like those made by the Secretary of Maryland in Fielder. Suffolk County argued that the five options meant that employers were not required to contribute money to the county and that because of this, employers were not left with a choice that required them to change their ERISA plans and thus the law should not be pre-empted. ${ }^{167}$ The court agreed with the Fielder Court, however, and found that although there were five choices, the only "rational choice employers have under [the Act] is to structure their ERISA healthcare benefit plans so as to meet the minimum spending threshold." 168 The options provided for in the act were not "meaningful" alternatives in the eyes of the court. ${ }^{169}$ First, the court noted that although employers may contribute to a health savings account under the Act, they cannot do so unless employees first set up the account and there is no guarantee that the employees would do so. ${ }^{170}$ The court also explained that on-site health services are unrealistic and impractical because in order for an employer to establish such a clinic that would not be governed under ERISA, the clinic would only be able to deal with the treatment of minor injuries or illnesses and would not be able to treat employees' family members. ${ }^{171}$ The court noted that allowing employers to contribute to a

161 Id. (citing HMI Mech. Sys. v. McGowan, 266 F>3d 142, 148 (2nd Cir. 2001); Egelhoff v. Egelhoff, 532 U.S. 141, 148 (2001)).

162463 U.S. 85 (1983).

$163 \quad 532$ U.S. 141

$164 \quad 633$ F.2d 760

$165 \quad 514$ U.S. 645

166 See supra Part I.

$167 \quad$ RILA v. Suffolk County, No. 06-531 (E.D.N.Y. July 14, 2007).

$168 \quad$ Id.

169 Id.

$170 \quad$ Id.

$171 \quad$ Id. The court agreed with the Fourth Circuit in Fielder and found that this would "simply not be a serious means by which employers could increase healthcare spending to comply with the Act." RILA v. Fielder, 475 F.3d 180, 196 (4th Cir. 2007). 
community health center was also not a viable option because declarations from Wal-Mart executives showed that they would not use this option in lieu of contributing to an employee's health plan. ${ }^{172}$ Finally, the court explained that although the Act provides that employers can reimburse employees for health care expenses, such reimbursement would require a plan and a plan administrator in order to ensure that this happened and this would be disruptive to the uniform plan requirement of ERISA, meaning the law should be pre-empted. ${ }^{173}$

Because of this, the court found the alternative options for compliance unrealistic and therefore that in order to comply with the Suffolk County law, Wal-Mart would have to change how they structure their employee benefit plan. ${ }^{174}$ The only option left for covered employers such as Wal-Mart under the Act after the unrealistic alternatives for compliance were ruled out would be to increase contributions to ERISA plans. ${ }^{175}$ The law would thus interfere with employers' administration of their ERISA plans because employers would have to vary benefits and change their system for the New York law. ${ }^{176}$ The court held that this clearly showed the law both had a connection with and related to employee benefit plans under ERISA and therefore the law should be pre-empted.

This opinion is almost an exact replica of the Fourth Circuit's Fielder decision. For this reason, we note again that the conclusion reached by the court was correct - the law, as written, should be pre-empted by ERISA because it directly relates to employee benefit plans. Allowing the Suffolk County law to remain in existence would defeat the Congressional intent of ERISA, which was to allow for a uniform application of employee benefits. The Suffolk County law shows one of the prime problems with the way legislatures word health care reform laws and, as the next two sections will illuminate, there are alternative constructions and statutory language that might be able to achieve the ultimate goal of providing insurance and reducing state health care costs, without suffering the same fate of ERISA pre-emption.

\section{III: Finding a BetTer Precedent: Standard OIL, HAWAII, AND Congressional InTENT}

From the late 1960's until ERISA was passed in 1974, there was an ongoing debate on the topic of compulsory national health insurance. ${ }^{177}$ The historical record does not indicate that whether there was a similar debate at the individual state level. In fact, only the state of Hawaii was seriously entertaining the possibility of mandated employer health coverage. And even Hawaii seemed to clearly recognize that this was a field that could one day be federalized. When the Hawaii Legislature enacted a law mandating compulsory health insurance, it included a

\footnotetext{
$172 \quad$ Suffolk County, No. 06-531.

$173 \quad$ Id. (citing Egelhoff v. Egelhoff, 532 U.S. 141, (2001)).

$174 \quad$ Id. (“ $[T]$ he amount of contribution required by the Act is more than Wal-Mart currently contributes and therefore, would require that Wal-Mart make a different expenditure for employees in Suffolk County than it does for employees in other states.”).

175 Suffolk County, No. 06-531

$176 \quad$ Id. (citing RILA v. Fielder, 475 F.3d 180, 193-94 (4th Cir. 2007)).

177 Starr, Paul, The Social Transformation of American Medicine, Basic Books, Inc. P: New York, 1982.
} 
clause in the statutory language which would invalidate the Act if a form of national health insurance was developed and implemented. ${ }^{178}$

When ERISA was passed in 1974, it did not provide for national health insurance. That same year Hawaii also passed its Prepaid Act - which mandated health insurance in the state but stated the law would be invalidated if there was federal compulsory health insurance. ${ }^{179}$ Thus, a debate quickly developed over whether or not ERISA pre-empted the Hawaii Prepaid Act. In Standard Oil v. Agsalud, ${ }^{180}$ the Eighth Circuit Court of Appeals upheld a district court's ruling that ERISA did, in fact, pre-empt the Hawaii Prepaid Act. ${ }^{181}$ In reaching their conclusion, the appellate court looked at the legislative history of ERISA for guidance as to how Congress intended the pre-emption clause to apply to state legislation. ${ }^{182}$ The Court reasoned:

“At the time ERISA was enacted, all private plans were voluntary as opposed to mandated by state law and ERISA itself does not require employers to provide plans. We cannot agree, however, with Hawaii's contention that Congress intended to exempt plans mandated by state statute from ERISA's coverage. Congress did distinguish between plans established or maintained by private employers for private employees and plans established or maintained by government entities for government employees. Such government plans are exempt. Private plans are not. The plans which Hawaii would require of private employers are not government plans. There is no express exemption from ERISA coverage for plans which state law requires private employers to provide their employees. The legislative history convincingly demonstrates a broad congressional preemptive intent. The plans envisioned under the Hawaii statute are therefore not rendered outside the definition of employee welfare benefit plans simply because Hawaii has attempted to make them mandatory."183

The appellate court's ruling was summarily affirmed by the Supreme Court. ${ }^{184}$

In 1983, President Ronald Reagan signed an amendment to ERISA that granted Hawaii a pre-emption exemption. ${ }^{185}$ Interestingly enough, an early form of the amendment had extended the Hawaii exemption to any state mandated employer health care law. ${ }^{186}$ The fact that Congress

178 The Hawaii Uninsured Project, A Historical Overview of Hawaii’s Prepaid Healthcare Act, No. 4-01, July 2004; See also http://www.statecoverage.net/statereports/hi6.pdf.

179 The Hawaii Prepaid Healthcare Act mandated certain benefits that employers were required to provide for their employees - including hospital, surgical, medical, laboratory, and maternity benefits. See http://www.hawaii.gov/labor/DO/phc_9-9-05/phc_9-9-05_files/frame.htm. (last visited July 30, 2007).

181

182

633 F. 2d 760 (9th Cir. 1980); aff'd, 454 U.S. 801 (1981).

Id. at 763.

Id. at 764 .

Id.

Standard Oil v. Agsalud, 454 U.S. 801 (1981).

U.S. Code, Annotated, Title 29, § 1144(a)

S.B. 1383 (1977). 
did not expand the exemption indicates an intention to preempt any state law that would mandate the creation of employee benefit plans. This is arguably the most important legal precedent that exists as far as mandated employer health care legislation and ERISA pre-emption challenges are concerned.

The value of Judge Renfrew's masterful analysis in Standard Oil is supported by the Supreme Court's recent ruling in Aetna Health Inc. v. Davila ${ }^{187}$. In Aetna, Justice Thomas reiterated that ERISA involved important policy choices on Congress' behalf. Aetna deals with the often frustrating issue of limited legal remedies provided by ERISA and the meaning of the phrase "some kind of equitable relief" in section 3. ${ }^{188}$ Specifically, this cases focus on state efforts to supplement the limited legal remedies available under ERISA. These cases don't initially seem to bear much on a case that involves the impact of the ERISA pre-emption clause on state legislation mandating employer health insurance spending. However, the fact that the Supreme Court clearly recognizes that the limited legal remedies Congress provided when they enacted ERISA were part of some sort of compromise is very important. This demonstrates that ERISA was drafted with the goal of providing incentives for employers to create employee benefit plans. If that was the case, then state laws mandating employee coverage directly undermine this compromise. If Congress had felt that mandating the creation of employee benefit plans was an exclusive state right, then they would not have bothered with an approach that seeks to balance competing interests.

The Supreme Court could take an entirely different approach and declare that the MFSA and any other state legislation that requires employers to provide health insurance coverage are automatically preempted, citing Standard Oil. The Fielder Court reached the same conclusion by applying its interpretation of $\underline{\text { Shaw }}$ and $\underline{\text { Travelers }}$ rather than using a more direct precedent. The Court's current test is confusing. If dissenting judge Judge Michael didn't believe the MFSA should be preempted, then we might presume that other federal judges may be similarly persuaded.

\section{IV: ANAlysis OF THE MFSA AND Other Similar Legislative ATTEMPTS}

The Maryland Fair Share Act is currently the only pure employer health care spending mandate to be enacted by a state. The fact that it was invalidated by the courts has not stopped other states from trying to pass similar legislation. At least 26 different states proposed similar legislation in 2006. ${ }^{189}$ After carefully reviewing all the bills that were introduced in 2006 and the three bills that have been introduced in 2007, it is clear that state legislatures, for the most part, have failed to demonstrate that "fair share" legislation can be drafted to withstand an ERISA preemption challenge. Almost all the "fair share" laws that have been proposed by state legislatures employ the same language that was used in the MFSA. For example, Minnesota H.B. 2786, ${ }^{190}$ which was introduced in February of 2006, reads:

\footnotetext{
$187 \quad 542$ U.S. 200 (2004).

$188 \quad$ See generally, $\underline{\text { id. }}$

189 See infra Part IV for an analysis of three such measures in Vermont, California, and Massachusetts.

190 H.F. 2786, Minnesota 84th legislative session (2005-2006), at www.revisor.leg.state.mn.us/bin/bldbill.php?bill=H2786.0.html\&session=ls84. The Minnesota law did not make it out of committee.
} 
"An employer with 10,000 or more employees in the state that is not organized as a nonprofit organization and does not spend at least ten percent of the total wages paid to employees in the state on health insurance costs shall pay to the commissioner an amount equal to the difference between what the employer spends for health insurance costs and an amount equal to ten percent of the total wages paid to employees in the state."191

The phrase "and does not spend at least ten percent ... on health insurance costs" is the major problem. This is a benefits mandate. As we saw in our discussion of Fielder and Suffolk County, the Shaw "connection with" test will likely lead a court to preempt this law because it relates to an employee benefit plan. This is exactly the type of language that should be avoided by lawmakers. Lawyers will have a hard time arguing that the purpose and effect of this bill is not to force employers to increase the health benefits they offer their employees.

Wisconsin Assembly Bill 860, ${ }^{192}$ introduced in December of 2005, demonstrates the flaws exhibited by earlier bills. It reads: "If an employer does not provide employer-subsidized health care coverage to all of its employees, the employer shall pay to the department an assessment that is equal to the cost incurred by society as a result of the employer not providing that coverage." 193 The phrase "employer-subsidized health care coverage" would most definitely set off preemption alarm bells. A court would most likely find that this bill directly references an ERISA plan. So, we should at least commend Maryland and other states for recognizing that "fair share" legislation should not directly refer to an employee welfare benefit plan.

Legislatures are starting to recognize that a state laws ability to withstand an ERISA challenge can often turn on seemingly insignificant word choices. Out of the three fair share bills already introduced in 2007, Minnesota H.B. $39^{194}$ and New Hampshire H.B. $579^{195}$ are structural replicas of the MFSA. This means that even if they are enacted they may be easily challenged in the courts. A prime example of this is the Suffolk County legislation, which had almost identical language to the MFSA and was preempted on the exact same grounds. ${ }^{196}$ One would think that the sponsors of these bills could have at least considered making some sort of changes that might provide the courts with a reason to reconsider the applicability of the Fielder decision to their legislation. The Michigan legislature has proposed a "fair share bill" that, at least in my opinion, is better suited to withstand a preemption challenge. Senate Bill No. $87^{197}$, titled "The Fair Share Health Fund Act," was introduced in January of 2007. It reads:

\footnotetext{
$191 \quad$ Id. at $\S 3$.

192 Wisconsin A.B. 860, available at www.ncsl.org/programs/health/payorplay2006.htm. The bill did not pass.

$193 \quad$ Id.

$194 \quad$ H.F. No. 39, Minnesota $85^{\text {th }}$ legislative session (2007-2008), available at www.revisor.leg.state.mn.us/bin/bldbill.php?bill=H0039.0.html\&session=ls85. The bill is currently with the Committee on Health and Human Services

195 HB 589-FN-A, New Hampshire 2007 session, available at www.gencourt.state.nh.us/legislation/2007/HB0579.

196 See RILA v. Suffolk County, No. 06-531 (E.D.N.Y. July 14, 2007) (Westlaw citation not available at date of submission); see also supra Part II.
} 
"For the calendar year 2008 and each subsequent year, there is imposed on an employer that is not organized as a nonprofit organization an annual fee that is initially established as the amount equal to $8 \%$ of the total annual wages that the employer pays to its employees minus the employer's annual health insurance costs, but not less than zero.»198

This is an interesting bill. Unlike other "fair share bills," the Michigan bill does a better job of disguising its mandate. It assesses a fee on employers, and it does not tie that fee to health insurance costs. It does offer a potential reduction in the fee that is based on an employer's health insurance costs, but that is merely a calculation issue. It can be argued that the purpose and effect of this law is not to mandate benefits. It is a naked attempt by the by the state to raise revenues for their Medicaid fund, and it is completely indifferent as to what an employer does with their ERISA plan. If this law werre to face a preemption challenge, the mostly likely argument that would be put forth by opponents of the law will be that the $8 \%$ wage fee amounts to a substantive benefits mandate or Hobson's choice. However, the Michigan legislature should not worry too much about this. The Hobson's choice discussed in Travelers required a state law to somehow bind plan administrators to certain choices and the Michigan law does not operate in such a fashion. It is a flat fee that will be applied on a class of employers (those with 10,000 or more employees) irrespective of whether they administer ERISA plans, and is thus more comparable to a state payroll tax. The only ERISA concern arises in the offset that the law offers employers for their annual health care costs. This, however, would not satisfy the definition of an ERISA plan and would save the bill from preemption.

The proposed Michigan bill and the MFSA have the same ultimate goal. They will also produce almost identical outcomes. The only real difference between the two bills is in the language employed by the legislature. Because it is carefully drafted, the Michigan bill may not interfere with the uniform administration of an ERISA plan. The MFSA cannot make the same claim, even though the only apparent difference between the two laws is that the MFSA chose to state its purpose within the language of the regulation while the Michigan bill chose to remain silent. If the Michigan bill is ever enacted, a court may still be able to preempt it, however, on the grounds that the fee is really just a thinly veiled benefits mandate. But for that to happen, the courts would have to basically conclude that Congress intended to preempt any attempts by the states to create employer healthcare spending mandates. In any event, the Michigan bill demonstrates that legislatures, by remaining silent, can draft health care legislation that may be more immune to ERISA challenges.

Ultimately, it is hard to get around the simple fact that the bills in question are often labeled as "fair share" legislation. "Fair share" implies that the state is forcing employers to pay their fair share of employee health benefit costs. The predominant way by which employers pay employee health benefit costs is through an ERISA plan. Thus, states are going to have a difficult time arguing that there is no connection to an ERISA plan if you have to defend a "fair share" bill. The one encouraging piece of "fair share" legislation, the aforementioned Michigan Bill, does not call for employers to per se "pay their fair share.” In fact, if it was more

197 “The Fair Share Healthcare Fund Act”, Michigan, Senate Bill No. 87, introduced January $25,2007$. available at www.legislature.mi.gov/documents/2007-2008/billintroduced/Senate/pdf/2007-SIB-0087.pdf. The bill is currently with Committee on Commerce and Tourism.

198

Id. at $\S 7$. 
appropriately named by the legislature, it would fall in the class of tax legislation and not healthcare legislation. We would thus advise legislatures to seriously reconsider "fair share" proposals as a means of regulating health care costs. The states would be better served to focus their time and efforts on other forms of health care reform. We would also note that a cursory examination of all the proposed bills in 2006 revealed that state assessments varied from $6 \%$ to almost $12 \% .{ }^{199}$ This is prima facie evidence of inconsistent state regulation of an ERISA plan that will be extremely difficult to overcome.

\section{V: Alternative Approaches to “Fair Share” Legislation}

\section{A. Pay or Play Tax}

Legislatures seeking to avoid ERISA pre-emption have come up with a more defensible method of state mandated employer health coverage, called pay or play legislation. Such legislation offers some clear advantages over the ERISA-prone "fair share” acts. The phrase "pay or play" refers exclusively to legislation that can be characterized as a tax or fee. Generally speaking, a pay or play bill is a broad tax that is assessed on employer payrolls and an employer must pay this tax to a state fund that will be used to supplement Medicaid costs. Employers can then obtain a credit against this tax for any health care benefits they already provide. These laws have the advantage of being completely neutral as to whether or not an employer chooses to provide employee benefit plans. They also directly target the employer, and do not in any way target the healthcare plan. These laws target a broad group of employers and they can be identified as tax legislation. As we previously discussed, the Secretary of Maryland attempted to defend the MFSA on the grounds that the assessment that was to be paid to the state was a tax and not a fee. ${ }^{200}$ One of the major problems the court had with his argument was that the assessments would not be collected by the treasury. ${ }^{201}$ This demonstrated to the court that the legislature was not treating the MFSA in the same way that it administered all other tax legislation. The court also criticized the Maryland law for targeting such a small class of employers. Thus, the legislature should make sure that any pay or play tax legislation is drafted the same way all other tax legislation is drafted and broadly aimed at many times of employers. Once this is accomplished, it should not be hard for states to structure the tax part of the legislation without causing ERISA problems. The area that seems to exhibit the most potential problems as far ERISA preemption is concerned is the part of the legislation that deals with employers who already offer benefits. The simple rule here is that tax credits should be offered for any and all health insurance coverage provided by employers, and employee eligibility in the state administered program should be unconditional. By following these basic requirements a state's pay or play law should have adequate ERISA preemption protection. Furthermore, the fact that such legislation employs the state's taxing authority is an inherent advantage when questions of federalism arise.

No state has successfully implemented a pure pay or play employee tax, but there have been a few serious proposals over the past 20 years. We will address each in turn.

199 2006-2007 Fair Share Healthcare Funds or 'Pay or Play Bills', Can states mandate employer health insurance benefits”, National Conference of State Legislatures, available at www.ncsl.org/programs/health/payorplay2007.htm.

$200 \quad$ RILA v. Fielder, 475 F.3d 180 (4th Cir. 2007).

201

Id. 


\section{Massachusetts}

In 1988, Michael Dukakis signed the Health Security Act. It required employers with more than five employees to pay a payroll tax of $12 \%$ on the first $\$ 14,000$ (\$1680) of annual wages per worker. ${ }^{202}$ Employers who already provide coverage would receive a credit against this tax. This is a pure form of pay or play legislation. An ERISA preemption challenge of this law would be limited to any reference that the law makes to an ERISA plan. In this case, the only apparent reference would be in the tax credit. Thus, like the Michigan bill, an employer would have to try and get the law pre-empted by arguing against the credit it aims to provide them. The Massachusetts Health Security Act was never implemented, and in 1996 the entire act was repealed. $^{203}$

\section{Oregon}

In 1989, Oregon enacted an employer pay or play program, although sponsors and the legislative intent clause also referred to it as an employer mandate. The law imposed a payroll tax on employers who had not provided employee and dependent coverage. ${ }^{204}$ The fund created with these tax revenues would be used by the state to buy health coverage for these employers' uninsured employees and dependents.

This law would have been more vulnerable to an ERISA preemption attack. In contrast to the Massachusetts law, the Oregon tax applied only to employers not covering their workers. The use of the word "not" in the statutory language to define the class of employers suggests a reference to an ERISA plan. Furthermore, the tax was set at 75 percent of the cost of a basic benefits package for employee coverage and 50 percent of this cost for dependent coverage. ${ }^{205}$ The basic benefits package would have been predetermined by the state. This creates the added problem of converting tax legislation into a benefits mandate. It is possible that under Standard Oil, a court may have entirely preempted the Oregon law for merely mandating employer health benefit spending of any kind. The Oregon law demonstrates that "pay or play" taxes can often be compromised by using "fair share" language. If a state wants to provide maximum ERISA preemption protection for its legislation, it should make sure that it avoids missteps like the ones made by the Oregon legislature.

The aforementioned pay or play laws all have one thing in common - they employ a state's taxing authority, special state tax laws and credits that are designed to affect healthcare plans that would otherwise be preempted. However, when the employers are receiving a credit it would be unlikely for them to challenge such a state tax law. This gives the state a unique legal

202 Patricia A. Butler, Revisiting Pay or Play: How States Could Expand Employer-Based Coverage Within

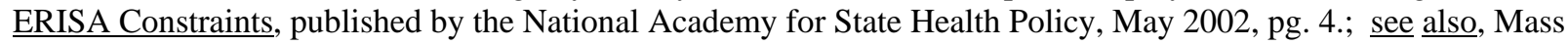
Labor and Industries Code 151A § 14g (1988 Massacusetts Acts, Ch. 23).

203 Implementation of the employer mandate was postponed three times due to stiff opposition from the business community, the election of a republican governor, and a recession in the national and local economy. The Act was finally repealed in 1996 . See $\underline{\text { id. }}$

204 Patricia A. Butler, Revisiting Pay or Play: How States Could Expand Employer-Based Coverage Within ERISA Constraints, published by the National Academy for State Health Policy, May 2002, pg. 4. 
advantage over fair share laws when ERISA preemption questions arise. State tax laws are not explicitly exempt from ERISA. If they were, states could use their tax laws to regulate ERISA plans. The federal Tax Injunction Act also bars federal courts from interfering with a state's "assessment, levy, or collection" of state taxes where there is a speedy remedy available in state court. ${ }^{206}$ The law is based on the principle of comity which precludes lawsuits involving potential federal court interference in the administration of state tax systems. Consequently, a state that enacted a pay or play tax can assert a jurisdictional defense against any ERISA preemption challenge that is filed in federal court. The Tax Injunction Act, however, would not prohibit an employer from challenging the state tax credits for employee health coverage in federal court. In the recent case of Hibbs v. Winn, ${ }^{207}$ the Supreme Court decided, in a narrow 54 ruling, that the Tax Injunction Act does not prevent third parties from challenging the constitutionality of state tax benefits in federal court. ${ }^{208}$ Whether an employer can use this argument to defeat the jurisdictional problem is an intriguing question and one which has yet to be confronted by the Court.

Although the tax nature of the pay or play legislation may provide preemption protection, the tax aspect can also be this legislation's greatest weakness. Tax laws for all practical purposes face significantly more political obstacles other than regulatory legislation. Since higher taxes are generally associated with lower growth, tax bills are generally not very popular. We would expect the business community to fiercely resist this type of legislation, especially if it becomes the only option to avoid preemption. There is also the added problem of supermajority requirements. Sixteen states currently require more than a majority to pass tax legislation. ${ }^{209}$ In those states, pay or play tax bills will most likely need support from more than the majority before they could be approved. It is for this reason that we are not very optimistic about the prospects for this approach as a means of avoiding ERISA preemption. While theoretically appealing, it is also probably impractical. If a legislature is willing to pass such legislation and can garner the support needed to do so, they should go one step further and implement a comprehensive state wide healthcare mandate.

\section{B. Comprehensive Health Care Bills}

Individual mandates are probably the best way to avoid ERISA preemption. This is because this type of legislation requires a comprehensive overhaul of the state's entire health care system. Under the Court's preemption doctrine, a presumption against preemption exists when matters of traditional state concern are involved. ${ }^{210}$ A comprehensive attempt by a state to provide healthcare for all its citizens would fall into this category. The argument would be that Congress most definitely did not intend to displace state laws that would provide healthcare for

\footnotetext{
206 Tax Injunction Act, 28 U.S.C. § 1341.

$207 \quad 542$ U.S. 88 (2003).

$208 \quad$ Id. at 112.
}

209 The states that require a 2/3 "supermajority” are Arizona, California, Colorado, Louisiana, Nevada, Oregon, South Dakota, and Washington. The states that require a 3/5 “supermajority” are Delaware, Florida, Missouri, and Oregon. The states that require a 3/4 "supermajority” are Arkansas, Michigan, and Oklahoma. See National Conference of State Legislatures at www.ncls.org (March 25, 2004) (last visited July 30, 1007). 
all their citizens when it passed ERISA. Thus, potential ERISA conflicts resulting from an individual mandate would most likely be viewed by the courts as indirect economic costs that do not warrant preemption. Vermont, California, and Massachusetts have successfully passed individual healthcare mandates. While Vermont and California's laws were later repealed, Massachusetts is currently implementing its mandate. A brief review of these three laws will demonstrate that they offer the most formidable obstacles to an ERISA based preemption challenge.

\section{Vermont}

Vermont House Bill 524, titled “An Act Relating to Universal Access to Health Care in Vermont," was passed in June of 2005. ${ }^{211}$ If it had been implemented, it would have created Green Mountain Health which would have been responsible for providing health care to all uninsured citizens in the state. Green Mountain Health would have been partially financed by a payroll tax on employers and an income tax on individuals. ${ }^{212}$ The state would offer unconditional credits against this tax for employers who already provided health coverage. ${ }^{213}$ Presumably, this type of law has a very good chance of withstanding an ERISA challenge. It can be argued that it is a tax on employer payrolls, and thus can be defended by the Tax Injunction Act. It is also part of a broader health care reform law, and thus is protected because it falls within an area of traditional state regulation. ${ }^{214}$ Finally, the law does not prohibit the uniform administration of ERISA plans, and is thus not the type of law Congress intended to preempt. The governor of Vermont, however, reached a different conclusion and vetoed the law. He reasoned that:

"[A] plausible and persuasive claim can be made that because, as a practical matter, the tax will be imposed principally on businesses that do not offer health coverage, the tax is nothing less than a legal mandate to offer coverage, or to offer a higher level of coverage than the business would otherwise offer. ERISA prohibits states from requiring employers to offer health care coverage, or from requiring employers to offer a prescribed level of benefits.",215

However, it is unclear whether or not Congress intended to preempt any and all employer healthcare spending requirements. Furthermore, the employer tax is a tax and not a health mandate. It does not require employers to increase benefits or even to increase spending on health insurance costs. It is merely a part of an extensive financing scheme to cover the state's uninsured - a financing scheme that holds both businesses and individuals accountable for a state health care crisis.

\footnotetext{
$211 \quad$ Vermont H. 524, full version available at www.leg.state.vt.us/docs/legdoc.cfm?URL=/docs/2006/journal/hj060104.htm. 


\section{California}

California SB 2 was enacted in 2004 and created the State Health Purchasing Program, which was to be administered by the Managed Risk Medical Insurance Board. ${ }^{216}$ The program would have been responsible for providing health care for all working Californians and when applicable, their dependents. ${ }^{217}$ The program was to be funded by both employer and enrollee contributions. $^{218}$ These contributions would then be collected in the form of an assessed fee. Employers would be eligible for a credit against this fee for any health care coverage that they already offered, provided their existing coverage satisfied certain minimum state requirements.

Whether or not this law would have survived an ERISA challenge would most likely have depended on the fee credit. ${ }^{219}$ According to SB 2, "[t]he board shall establish the level of the fee by determining the total amount necessary to pay for health care for all enrollees, and, if applicable, their dependents eligible for the program."220 Thus, the fee does not appear to be a problem, as it is based on the states cost for providing coverage and does not reference an ERISA plan. The credit, however, is conditioned on an employer providing certain benefits and paying $80 \%$ of an employee's premium. ${ }^{221}$ This part of the bill would likely be preempted because it both references and has a connection with an ERISA plan in a manner that would prevent the uniform administration and structure of the plan. ${ }^{222}$ Apparently the California legislature anticipated this problem and thus included a default provision that would go into effect if the credit was invalidated. Under the default rule, employer's can apply for an income tax credit for the cost of an employee health spending. This credit would be capped so as to not exceed the level of the state's Medi-Cal or Health Families coverage. Since this credit does not mandate benefits or reference an ERISA plan, it would most likely withstand preemption. Despite this, SB 2 was never implemented. On November 3, 2004, Californians voted to repeal the law - with a margin of $50.9 \%$ for repeal versus $49.1 \%$ against. ${ }^{223}$ The narrow margin indicates that the state is open to some kind of major healthcare reform in the near future.

\section{Massachusetts}

The Massachusetts Health Care Reform Act ${ }^{224}$ was signed into law on April 12, 2006, and is currently in the early stages of implementation. It is a comprehensive and unique piece of

\footnotetext{
216 California Health Insurance Act, SB 2.

$217 \quad$ Id.

$218 \quad$ Id.

219 The credit was conditioned on the fact that employers pay at least $80 \%$ of employee premiums and provide certain benefits. This would likely have made the law very vulnerable to an ERISA preemption challenge. See Patricia Butler, ERISA Implications for Sb2, 2004, available at (www.chcf.org)

220 California Sb.2 (2003 California Acts. Ch. 673), § 2 Ch. 4, available at www.leginfo.ca.gov/pub/0304/bill/sen/sb_0001-0050/sb_2_bill_20031006_chaptered.pdf.

221

222

223

Id. at $\S 2$ Ch. 6 .

Patricia Butler, ERISA implications for Sb2, 2004.

Id.

2006 Massachusetts Acts Ch..58, available at www.mass.gov/legis/laws/seslaw06/sl060058.htm.
} 
legislation that seeks to address both the problem of uninsured state residents and rising health care costs. The major reforms instituted by the Act include an individual health care mandate, an employer mandate consisting of a "fair share" provision and a "free rider" surcharge, and the establishment of a health insurance connector. The Massachusetts Act is considered to be a model for future state-health initiatives, and thus must be carefully examined for potential ERISA conflicts.

The most ambitious requirement in the Act is the individual health care mandate. As of July 1 2007, Massachusetts residents above the age of 18 and over must obtain credible health coverage. $^{225}$ For the most part, a group plan will meet the credible coverage requirement if it meets the minimum coverage level set by the Board of the Connector. ${ }^{226}$ Any individual who fails to obtain coverage risks losing his personal tax exemption for the year. This component of

$225 \quad$ Id. at $\S 2(a)$

226956 CMR 5.0 Minimum Credible Coverage. Currently Minimum credible coverage is met by any employee health benefit plan; however, in 2009 significantly more demanding standards will go into effect. See www.mass.gov/Qhic/docs/MCC\%20draft\%20regulations\%20956\%20CMR\%205.00.doc.

For the period beginning January 1, 2009 , any health benefit plan shall be providing minimum creditable coverage only if it satisfies all of the following requirements:

a. A health benefit plan must provide a broad range of medical benefits, including but not limited to, preventive and primary care, emergency services, hospitalization, ambulatory patient services, prescription drugs, and mental health services, all in accordance with state and federal statues and regulations governing the particular health benefit plan.

b. A health benefit plan may impose reasonable exclusions and limitations, including different benefit levels for in-network and out-of-network providers.

c. A health benefit plan may impose varied levels of co-payments, deductibles and co-insurance, provided that:

(1) the plan must disclose to covered persons the deductible, co-payment and co-insurance amounts applicable to in-network and out-of-network covered services;

(2) any deductible for in-network covered services shall not exceed \$2,000 for an individual and $\$ 4,000$ for a family; and

(3) any separate deductible imposed for prescription drug coverage shall not exceed $\$ 250$ for an individual and $\$ 500$ for a family.

d. If a health benefit plan includes deductibles or co-insurance, the plan must set out-of-pocket maximums for in-network covered services that do not exceed $\$ 5,000$ for an individual and $\$ 10,000$ for a family; provided, however, that this requirement shall not apply to a health benefit plan that includes co-insurance only for a limited number of select covered services.

e. A health benefit plan's calculation of any out-of-pocket maximum must include all the following payments for covered services made by the individual or family: co-payments over $\$ 100$, coinsurance and deductibles; provided, however, that amounts paid for prescription drugs, whether through deductibles, coinsurance or co-payments, need not be considered in calculating the out-of pocket maximum.

f. A health benefit plan may not impose an annual maximum benefit or a per illness annual maximum benefit for covered services.

g. A health benefit plan may not impose a fee schedule of indemnity benefits for covered services. 
the law doesn't seem to raise any ERISA preemption issues because the law targets individuals and not employee benefit plans.

The Massachusetts Act also establishes a public entity - the "connector," which serves as a voluntary health insurance purchasing cooperative arrangement for eligible individuals and for small employer groups that choose to participate. The stated purpose of the "connector" is to facilitate the availability, choice, and adoption of private health insurance plans at an affordable price. $^{227}$ A participating small employer must enter into a binding agreement that "the employer will not offer a separate and competing group health plan; and that the employer reserves the right to determine criteria for its employee's eligibility, enrollment, participation, and premium contribution requirements." 228 Since the main purpose of the Connector is providing affordable health insurance to small employers and individuals, it may not be preempted by ERISA. The Courts would classify the Connector as a form of insurance regulation that would be saved from preemption under ERISA's savings clause. $^{229}$

The Massachusetts law also includes a "fair share" provision that requires employers to pay a \$295 assessment fee if they do not provide employees with a "fair and reasonable" contribution to their employee health plan. ${ }^{230}$ This part of the Act raises ERISA preemption concerns. Since the language employed by the legislature is the same "fair share" language used in the MFSA, we have to presume that this type of law would be preempted by ERISA. The main purpose and effect of the law is to mandate employer spending on employee welfare benefit plans. While the assessment of $\$ 295$ per employee by itself wouldn’t prohibit the uniform administration of employee benefit plans, if other states are able to follow in Massachusetts footsteps, national employers would not be able to effectively offer and administer one national employee benefit plan. According to the Travelers Court, this is exactly the type of law Congress intended to preempt under Section 514(a) of ERISA. Some people have incorrectly argued that the Fair Share provision in the Massachusetts Act would survive a preemption challenge on the grounds that it only produces an indirect economic effect on ERISA plans. While we acknowledge that the Massachusetts law falls into the category of broad health regulations that Congress didn't envision preempting when it passed ERISA, the "fair share" provision of the law has an impermissible connection with an employee benefit plan. Applying Travelers the Court will not preempt otherwise permissible state laws that indirectly produce some sort of economic effect on ERISA plans. Travelers never stated that certain provisions of a state law may survive an ERISA challenge simply because they affect plans as part of a greater comprehensive state regulation. The "fair share" provision of the Massachusetts law is connected with an ERISA regulated employee benefit plan through operation of law; it is thus preempted by ERISA. Furthermore, the Massachusetts "fair share" provision also directly references an ERISA plan. According to the Act, a company makes a "fair and reasonable" contribution if at least 25 percent of its full-time employees are enrolled in the group health plan

227 Massachusetts General Laws Ch. 176Q, § 16 (2006).

228 Id.

22929 U.S.C. $§ 1144(\mathrm{~b})(2)(\mathrm{a})$. Laws that regulate Insurance are saved from preemption under $\S 1144(\mathrm{a})$. Whether or not the connector would be deemed to be a law that regulates insurance would depend on whether it passed the Supreme Court's test in Kentucky Ass'n of Health Plans, Inc. et. al. v. Miller, Commissioner, Kentucky Dept. of Ins., 538 U.S. 329 (2003). 
and the company is making a contribution or if the company offers to pay at least 33 percent of an individual's health insurance premium. ${ }^{231}$ This is a direct reference to an ERISA plan. The Court has repeatedly preempted state laws simply for making textual references to an ERISA plan. Thus, the "fair share" provision of the Act is at risk of being preempted. This, of course, leads to the undesired result of ERISA preempting part of a comprehensive state health care initiative. This would produce an outcome where one part of a law was preempted and the other was not. Regrettably, this outcome cannot be avoided if the Court's current preemption doctrine is applied. As we stated earlier, states seeking to force employers to bear the burden of rising health care costs should abandon "fair share" laws or provisions.

The Massachusetts Act also requires employers to establish IRC Section 125 cafeteria plans to allow for employers and employees to make pre-tax contributions for health insurance premiums. If an employer does not establish such a plan, the Act authorizes the State to assess a "free rider" surcharge on any employer with an individual employee who receives free care more than three times in a year, or any group of employees that access free care a total of five times in a fiscal year. ${ }^{232}$ This surcharge raises some difficult preemption questions. Some scholars have argued that it can also be compared to the hospital surcharge in Travelers, and thus would not be preempted by ERISA. A cafeteria plan by itself may not relate to an employee welfare benefit plan as it is simply a pre-tax financing mechanism for health care coverage, however, the free rider surcharge does not convert it into such a plan. The financing arrangement must be established to avoid the costs that might be incurred by a plan's failure to provide adequate health coverage. If an employer does not provide a Section 125 plan and also doesn't provide adequate health coverage, they could be potentially crippled by an employee who experiences a catastrophic medical event. Thus, every employer in the Massachusetts area will be forced to adopt such a plan. This regulation is in no way comparable to the hospital surcharges in Travelers. The Massachusetts surcharge targets employer sponsored health coverage, coverage that is almost exclusively offered by ERISA-regulated welfare benefit plans. It also operates in such a manner as to leave employers no choice other than to offer a 125 plan in conjunction with or in place of an ERISA plan to avoid the costs associated with paying for state provided health care for their employees. An employer that does not offer a Section 125 plan would have to structure their benefit plan in such a way as to ensure that all employees at least receive catastrophic care coverage. This would be deemed to be a substantive health benefits mandate.

The Massachusetts law demonstrates that even the most comprehensive state health initiative is likely to cause ERISA preemption concerns if it incorporates any form of an employer mandate. These concerns can be minimized by carefully crafted provisions or flat out taxes, but will most likely never be entirely eliminated. This is simply because any meaningful health care reform law requires some type of employer mandate/financing initiative. Any law that does not incorporate this element will probably not be economically viable. Litigation over these issues will be extremely complex and it would behoove companies or the courts to revisit the broad question of whether or not an employer health care spending mandate is preempted by ERISA. If they are, in fact, preempted under ERISA as is suggested by the Court's affirmation of Standard Oil, the states can at least start focusing their efforts on getting Congress or the President to take the steps needed to address this crisis. However, if they are not preempted by

\begin{tabular}{ll}
\hline 231 & $\underline{\text { Id. }}$ \\
232 & Id.
\end{tabular}


ERISA, then I would encourage the Court to at least revisit the Travelers line of cases and clarify what type of state health care laws can survive an ERISA challenge.

\section{VI: How To Avoid Preemption of State HeAlthcare LAWS}

State legislatures should be able to tailor healthcare legislation to withstand ERISA challenges by following some very basic steps. First, a legislature should decide whether or not its legislation is going to be narrow or comprehensive. A basic employer-spending mandate like the MFSA or the Suffolk County law will always be at a disadvantage when compared to a comprehensive piece of healthcare legislation. Thus, legislators should incorporate employer mandates into broader health initiatives. This has the benefit of providing the maximum protection afforded by the "traditional state regulation" argument. Second, legislatures should seriously think about whether or not a "fair share" regulation can be converted into a tax. If they believe they can still sell the law as a tax, they should seriously consider a conversion. The tax designation will provide some added ERISA preemption protection if the law is ever challenged. If a legislature can't take advantage of these two principles and really only wants to pass an employer assessment, the legislation should be carefully drafted to avoid any possible references to an ERISA plan - such as not using the traditional "an employer who does not spend" language used in many state statutes. It is difficult to conceive of an approach that states could use to account for an employer's current health care spending in their legislation that does not in some way refer to the contributions made by such employers through an ERISA plan.

However, if the Court narrows the ERISA preemption doctrine and holds that welfare benefit plans are also always preempted, then conceivably any employer spending mandate will be preempted. ${ }^{23}$ This is because it will be next to impossible for legislatures to pass anything other than a standard payroll tax without somehow acknowledging that employers currently provide health benefits through welfare plans protected by ERISA. At which point, legislatures will have to wait and see whether or not a health care based payroll tax that offers no offsets or credits can be challenged on ERISA grounds. If the courts should find that these payroll taxes can be preempted, states will need to find alternative sources to fund their Medicaid programs. This would most likely be accomplished by resorting to state income or sales taxes, which is not desirable.

\section{CONCLUSION}

$\underline{\text { RILA v. Fielder }}^{234}$ demonstrates that sound legal analysis often produces undesirable social consequences. This is, of course, not news to most legal scholars. While we agree with the court's ruling in Fielder on the preemption issue, it proves that perhaps the implementation of ERISA has gone beyond the scope of what Congress intended. When Congress enacted ERISA in 1974, they were providing legislation that they thought would protect employee retirement benefits, a pressing concern considering the disastrous effect of the Studebaker pension fiasco. They did not intend to create legislation that would effectively bar or seriously hamper a states ability to provide for the welfare of its citizens. Employee health benefits were viewed as voluntary in 1974, and Congress enacted ERISA under such a framework. The Hawaii exemption demonstrates that by 1983, Congress' opinion had not changed. The preemption

$233 \quad$ See Mackey v. Lanier Collection Agency \& Service, Inc., 486 U.S. 825 (1988) (pre-empting a Georgia law in part that provided different procedures for welfare benefit plans on the grounds that it references ERISA plans). 
clause was included to encourage employers to offer health benefits on a national scale. The clause becomes obsolete if states can impose their own spending requirements on employers. Simply put, why provide a mechanism for uniformity if your already conceding that lack of uniformity is a plausible alternative?

Our analysis indicates that there are clear alternatives to employer mandates that should, if properly implemented, withstand ERISA preemption challenges. One of these alternatives is taxation. Many people have made this argument, and our analysis has shown that some states are already taking this advice. Tax legislation will allow the states to address the Medicaid funding issue and greater healthcare problem as it unfolds at the local level. This permits states that do not have the luxury of waiting for Congress to come up with an answer to start dealing with healthcare problems on their own. Ultimately, if Congress does not act, all states will have no choice but to employ some form of taxation as a means to address rising healthcare costs and an aging population. States that do not raise their taxes will find themselves at a significant disadvantage and they will either need to generate more revenue in other areas, or cut non-health care related spending to compete. If they choose to do nothing, they will face the social consequences of failing to address the basic needs of their citizens.

Another option is the individual health care mandate. This involves comprehensive legislation providing all the residents of a state with health insurance. These plans can be funded by a combination of taxes and assessments. The vetoed Vermont bill and certain components of the current Massachusetts act demonstrate that meaningful reforms can be made without triggering ERISA preemption. Since individual mandates don't take a piecemeal approach to health care reform, they are better suited to withstand preemption challenges. The fact that two laws that involving health care mandates were passed last year signals that the climate is changing. Health care reform is gaining momentum, and employers should start accepting the harsh reality that they will have to deal with the problem of cost containment. If they choose not to, state and local governments will be forced to fill the gap.

Furthermore, the Supreme Court will most likely have to visit the issue of mandated employer health care spending at some point in the near future. The upcoming national election and varying state initiatives almost guarantee this. In addition, a prolonged housing slump and the adverse impact it could have on state revenues would prompt even more states to consider some form of mandated employer health coverage, and encourage those that already have, to be more aggressive and creative with their legislation. Whether the case will involve the MSFA or some other related legislation is irrelevant. If the court finds, as our previous analysis suggested, that legislation mandating an employer to provide a certain level of health spending is preempted by ERISA, states will be forced to rely on their taxing power for any meaningful solution. This would immediately place pressure on Congress to revisit ERISA within the context of the current national health care climate. The Court can force the issue by simply limiting their analysis to benefit mandate preemption, while simultaneously acknowledging that over the past 30 years the belief that employer health care spending is a voluntary choice is gradually being replaced by the belief that it is a mandated responsibility. Congress could then either amend ERISA and allow states to pass regulatory legislation that more narrowly addresses their Medicaid or local health care concerns (targeting Wal-Mart and other employers with a disproportionate amount of lower income wages is more appealing to legislatures than passing a pay or play tax that affects thousands of businesses), or remain silent and thus acknowledge that taxation is the current acceptable remedy for health care problems. In considering their course of 
action, the Court should pay close attention to the parting words Judge Renfrew offered before he granted Standard Oil's motion for summary judgment:

"The workers whom ERISA was primarily intended to protect may be better off with state health insurance laws than without them, and the efforts of states like Hawaii to ensure that their citizens have low-cost comprehensive health insurance may be significantly impaired by ERISA's preemption of health insurance laws. Federal legislators should heed the admonition that Justice Brandeis addressed to the federal courts: "[t]o stay experimentation in things social and economic is a grave responsibility. Denial of the right to experiment may be fraught with serious consequences to the Nation. It is one of the happy incidents of the federal system that a single courageous State may, if its citizens choose, serve as a laboratory; and try novel social and economic experiments without risk to the rest of the country.' Although this social experiment of Hawaii may pose no 'risk to the rest of the country,' it does impose a burden on interstate commerce which Congress has the power to remove. Not the courts but the legislatures possess the primary responsibility to balance the interests of the national economy against the interests of the federal system. The Constitution places limits on that balancing, but Congress has not crossed those limits here. Defendants' remedy, if a remedy is necessary, is not in this Court but in Congress." ${ }^{235}$

Judge Renfrew's words, even though they were written 30 years ago, strike at the heart of the problem posed by the MFSA and similar legislation. Namely, what are the courts to do when sound legal analysis consistently produces inequitable results? Whatever is decided, one thing remains clear: there is a healthcare crisis that is developing on a national level. Not addressing this problem and its disparate impact may one day be considered this nation's greatest failure.

235 Standard Oil Co. of California v. Agsalud, 442 F.Supp. 695, 711 (D.C.Cal. 1977) (citations omitted). 